\title{
21. AGGLUTINATED BENTHIC FORAMINIFERS FROM UPPER CRETACEOUS VARIEGATED CLAYS OF THE NORTH ATLANTIC OCEAN (DSDP LEG 93 AND ODP LEG 103) ${ }^{1}$
}

\author{
Michel Moullade, Laboratoire de Géologie et Micropaléontologie Marines, Université de Nice, Nice, France \\ and \\ Wolfgang Kuhnt and Jürgen Thurow, Geologisch-Paläontologisches Institut, Universität Tübingen, Tübingen, \\ Federal Republic of Germany
}

\begin{abstract}
A reexamination of the agglutinated benthic foraminiferal microfaunas found in the Upper Cretaceous red and brown clays of DSDP Hole 603B and ODP Holes 640A and 641A allows us to refine the initial shipboard biostratigraphic interpretation and to propose a fourfold zonation that can be used with some precautions in the oceanic realm. By means of various calibrations, an attempt is also made to integrate this zonation in a worldwide chronostratigraphic framework. The resulting chronologic control permits us to discern large differences in the rhythm of red clay deposition on either side of the North Atlantic Ocean.
\end{abstract}

\section{INTRODUCTION}

During the last decade, various authors (Krasheninnikov, 1973, 1974; Rögl, 1976; Krasheninnikov and Pflaumann, 1977; McNulty, 1979, 1984; Sigal, 1979; Hemleben and Troester, 1984) have reported occurrences of deep-water agglutinated benthic foraminiferal assemblages from predominantly Upper Cretaceous red/brown clays recovered by deep drilling in the Pacific, Indian, and Atlantic oceans. Most of these oceanic taxa are new, although a few of them were originally described from flyschtype deposits of the Alpine-Carpathian orogenic belt. However, uncertainty remained as to whether these apparently long-ranging "primitive" foraminifers could be used as stratigraphic markers. If so, they would prove useful in the study of deep marine sediments, which are generally devoid of calcareous microfaunas. Geroch and Nowak (1984) proposed a zonation based only on agglutinants for the upper Tithonian-Eocene section in the Polish Outer Carpathians. No such formal attempt has been made for the oceanic realm, although Krasheninnikov (1974) demonstrated the superposition of two distinct faunal assemblages in the Upper Cretaceous deposits drilled at Hole 261 during Deep Sea Drilling Project (DSDP) Leg 27.

We were thus encouraged to conduct a detailed investigation of the supposedly continuous Upper Cretaceous sections recently drilled in the North Atlantic Ocean at Hole 603B (DSDP Leg 93) and Holes 640A and 641A (Ocean Drilling Program (ODP) Leg 103). At all of these sites the Upper Cretaceous sequence consists dominantly of brown clay containing moderately to relatively well-preserved and diverse agglutinated benthic foraminiferal assemblages. Hole 603B is located along the American North Atlantic margin (Fig. 1), at $35^{\circ} 29.71^{\prime} \mathrm{N}$ and in a water depth of $4633 \mathrm{~m}$. For this paper, the preliminary shipboard study of Upper Cretaceous foraminifers from Site 603 (van Hinte, Wise, et al., 1987) was revised and expanded by the senior author, and a thorough revision of the radiolarians made (Thurow). Holes 640A and 641A were drilled along the European North Atlantic margin (Fig. 2), at $42^{\circ} 00.7^{\prime} \mathrm{N}$ in a water depth

${ }^{1}$ Boillot, G., Winterer, E. L., et al., 1988. Proc. ODP, Sci. Results, 103: College Station, TX (Ocean Drilling Program). of $5196 \mathrm{~m}$ and at $42^{\circ} 09.3^{\prime} \mathrm{N}$ in a water depth of $4639 \mathrm{~m}$, respectively. The Upper Cretaceous foraminifers from the Leg 103 holes were studied separately in two distinct sets of samples by Moullade and Kuhnt, and the results were cross-checked and combined.

\section{BIOSTRATIGRAPHY}

\section{Biostratigraphic Distribution of Agglutinants}

The in-situ foraminiferal assemblages of the Upper Cretaceous sequences studied in Holes 603B, 640A, and 641A are composed exclusively of agglutinated benthic specimens belonging to the Recurvoides association defined by Haig (1979) or a B-type assemblage of Gradstein and Berggren (1981). A few samples from each site also contain extremely rare and tiny nonkeeled Cretaceous planktonic foraminifers, which can be reasonably interpreted as transported material, presumably contemporaneous with the in-situ fauna. In addition, particularly in Hole 641A, Neogene and/or Quaternary specimens (chiefly planktonics) occur sporadically. These specimens seem to have resulted mainly from downhole contamination, with the excep-

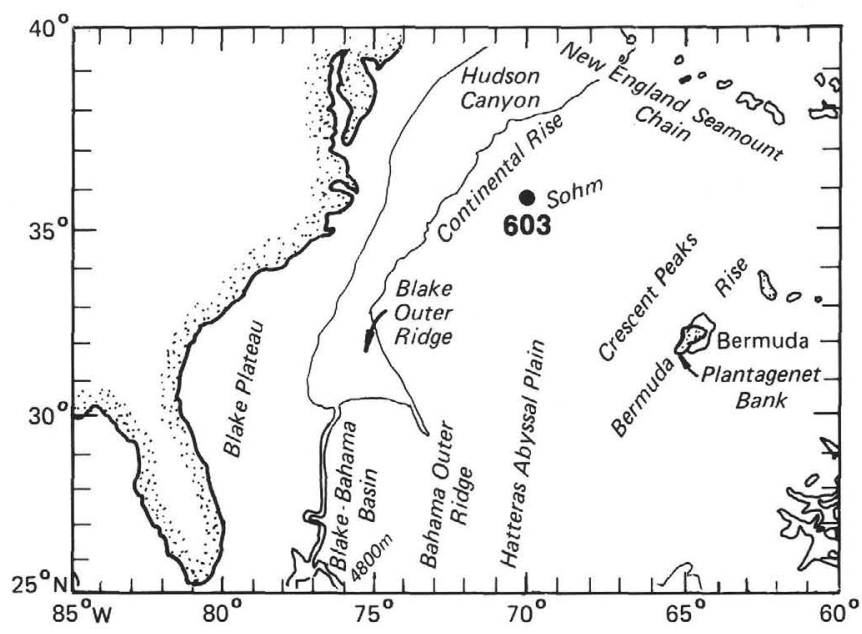

Figure 1. Location of DSDP Hole 603. 
A

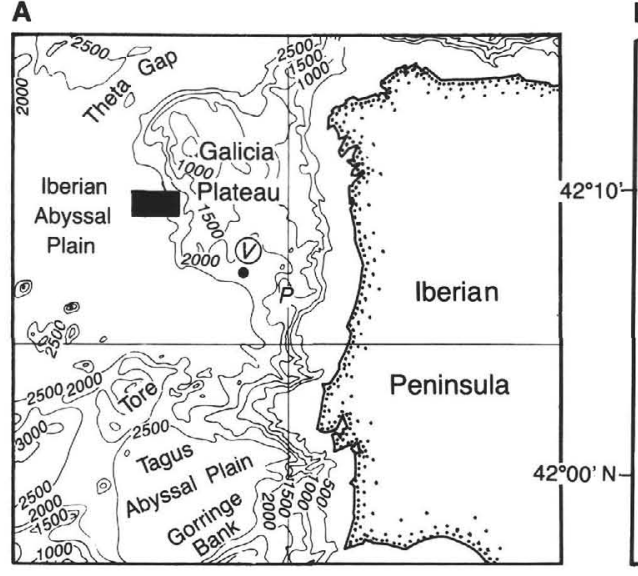

B

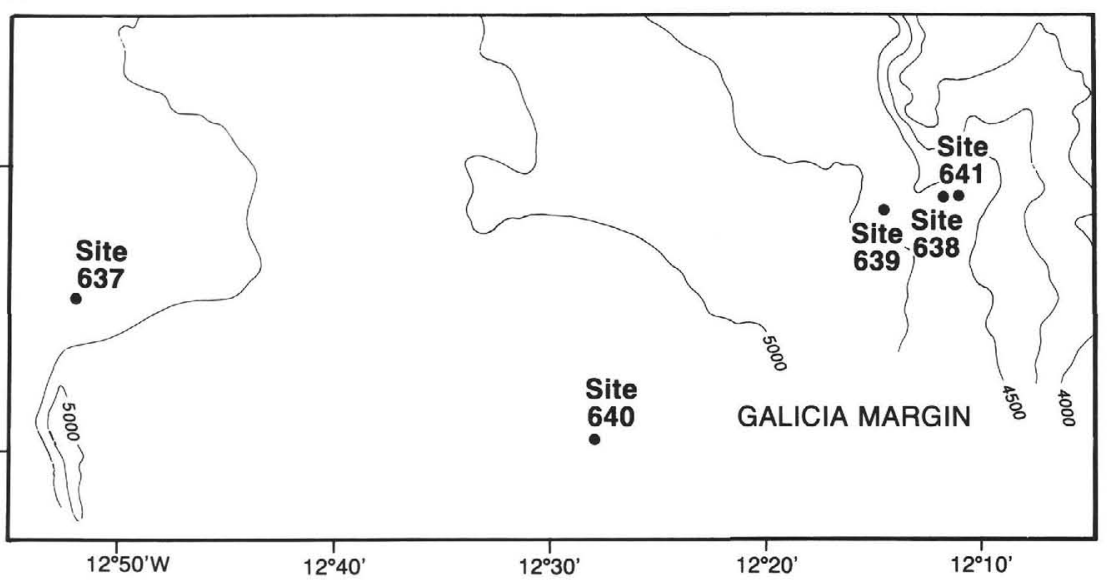

Figure 2. Location of ODP Leg 103 sites. Solid rectangle in Figure 2A shows area covered by Figure 2B. Bathymetry in meters.

tion of those found in the first two cores of Hole 641A (see following discussion).

\section{Hole 641 A}

The lower boundary of the Upper Cretaceous interval that contains agglutinated foraminifers coincides with Sample 103$641 \mathrm{~A}-6 \mathrm{X}-7,26-29 \mathrm{~cm}$, which straddles the lithologic contact between the brown/green clays and an underlying 25 -cm-thick homogeneous black band. Upper Cretaceous agglutinated foraminifers are regularly present in the 52-m-thick section from this sample up to Sample 103-641A-1X-2, 28-32 cm. Lower Pleistocene nannofossils are found above this interval (see "Biostratigraphy" section of "Site 641" chapter; Boillot, Winterer, et al., 1987), in Section 103-641A-1X-1, but samples taken from the interval from Sections 103-641A-1X-2 to 103-641A-2X, CC, reveal a generally significant Neogene and/or (mainly) Quaternary foraminiferal component, with the percentage decreasing in a general downhole trend.

Most of Core 103-641 A-2X appears to be lithologically heterogeneous, consisting of brown clay mixed with clasts of various ages, and might be partly or totally reworked and/or slumped (see "Sediment Lithology" section of "Site 641" chapter; Boillot, Winterer, et al., 1987). However, samples taken from brownish clays of the heterogeneous interval also contain (in amounts increasing rapidly downcore from $30 \%$ to $95 \%$ ) Upper Cretaceous agglutinated foraminifers. Moreover, it appears that the succession of Cretaceous taxa in this upper part of Hole 641A is stratigraphically consistent with the data obtained from the corresponding (and undisturbed) part of Hole 603B (see the following text). We are therefore led to include most of the samples from Cores 103-641A-1X and 103-641A-2X in our foraminiferal study, with the exception of those samples taken from obvious allochthonous clasts, as distinguished by color.

The distribution and relative abundance (estimated by visual examination) of Upper Cretaceous agglutinated foraminifers in Hole 641A are shown in Figure 3. A significant part (average $30 \%$ ) of the assemblages is made of tubelike specimens, belonging to the stratigraphically unsignificant Bathysiphon/Rhabdammina/Rhizammina/Dendrophrya Complex, which we have not separated at the specific level. Species such as Plectina gr. lenisconversa, Pseudobolivina gr. munda-lagenaria, Ammodiscus spp., and Glomospira spp., appear also as long-ranging taxa that are found throughout the entire microfossiliferous interval studied. However, a few species have a more restricted stratigraphic distribution; four species can be considered as good markers because they show a well-defined range in which they are regularly present in sufficient (i.e., at least $>1 \%$ ) abundance:
Haplophragmium lueckei is found only in Core 103-641A6X and the lower part of Core 103-641A-5X and disappears in Sample 641A-5X-3, 41-45 cm;

Praecystammina globigerinaeformis first appears in Sample 103-641 A-6X-6, 33-37 cm, and disappears in Section 103-641 A$3 \mathrm{X}, \mathrm{CC}$;

Uvigerinammina jankoi first appears at the base of Core 103-641A-6X and disappears in Sample 103-641A-3X-2, 102$106 \mathrm{~cm}$;

Hormosina gigantea is restricted to Cores 103-641A-3X to 103-641A-1X and becomes extinct in Sample 103-641A-1X-2, $109-114 \mathrm{~cm}$.

A few additional taxa also have a restricted range but are too episodic and scanty in occurrence to be considered as prime biostratigraphic markers:

Haplophragmoides bulloides, limited to Cores 103-641A-6X and 103-641A-5X;

Reophax sp. aff. dentaliniformis, with the same distribution as $P$. globigerinaeformis but much less regular;

Trochammina altiformis, very rare from Sample 103-641A$6 \mathrm{X}-3,21-25 \mathrm{~cm}$, up to Section 103-641A-3X, CC;

Haplophragmoides perexplicatus, found irregularly from Samples 103-641A-5X-1, 14-18 cm, up to 103-641A-1X-4, 12$17 \mathrm{~cm}$.

In addition, Recurvoides spp. and Paratrochamminoides spp., which are not present in Core 103-641A-6X and rare in Core 103-641A-5X, are much more abundant in the upper part of the sequence, in the interval from Cores 103-641A-4X to 103-641A-1X.

\section{Hole $603 B$}

In Hole 603B, the contact between the middle Cretaceous Hatteras Formation, composed predominantly of dark shales, and the Upper Cretaceous-?lower Paleogene Plantagenet Formation (reddish/greenish clay) occurs at $60 \mathrm{~cm}$ in Section 603B33-1 (Van Hinte, Wise, et al., 1987). Agglutinated foraminifers are extremely rare in the Hatteras black shales and even totally absent in the topmost part of the formation, whereas they have several long intervals of consistent occurrence separated by short barren episodes (characterized by abundant radiolarians) in the Plantagenet variegated claystones. The red clays extend from Samples $603 \mathrm{~B}-33-1,60 \mathrm{~cm}$, to $603 \mathrm{~B}-22-2,68 \mathrm{~cm}$, forming a 96-m-thick interval that is almost as twice as thick as the redbrown clay section in Hole 641A.

The diversity and composition of foraminiferal assemblages in Hole 603B (Fig. 4) are very similar to those found in Hole $641 \mathrm{~A}$, but the preservation is generally better, particularly in the interval from Cores 603B-32 to 603B-29. Neogene downhole 
- Very rare

(species per sample)

O Rare (1-3)

$\theta$ Few $( \pm 5)$

Common $(>10)$

Abundant (>50)

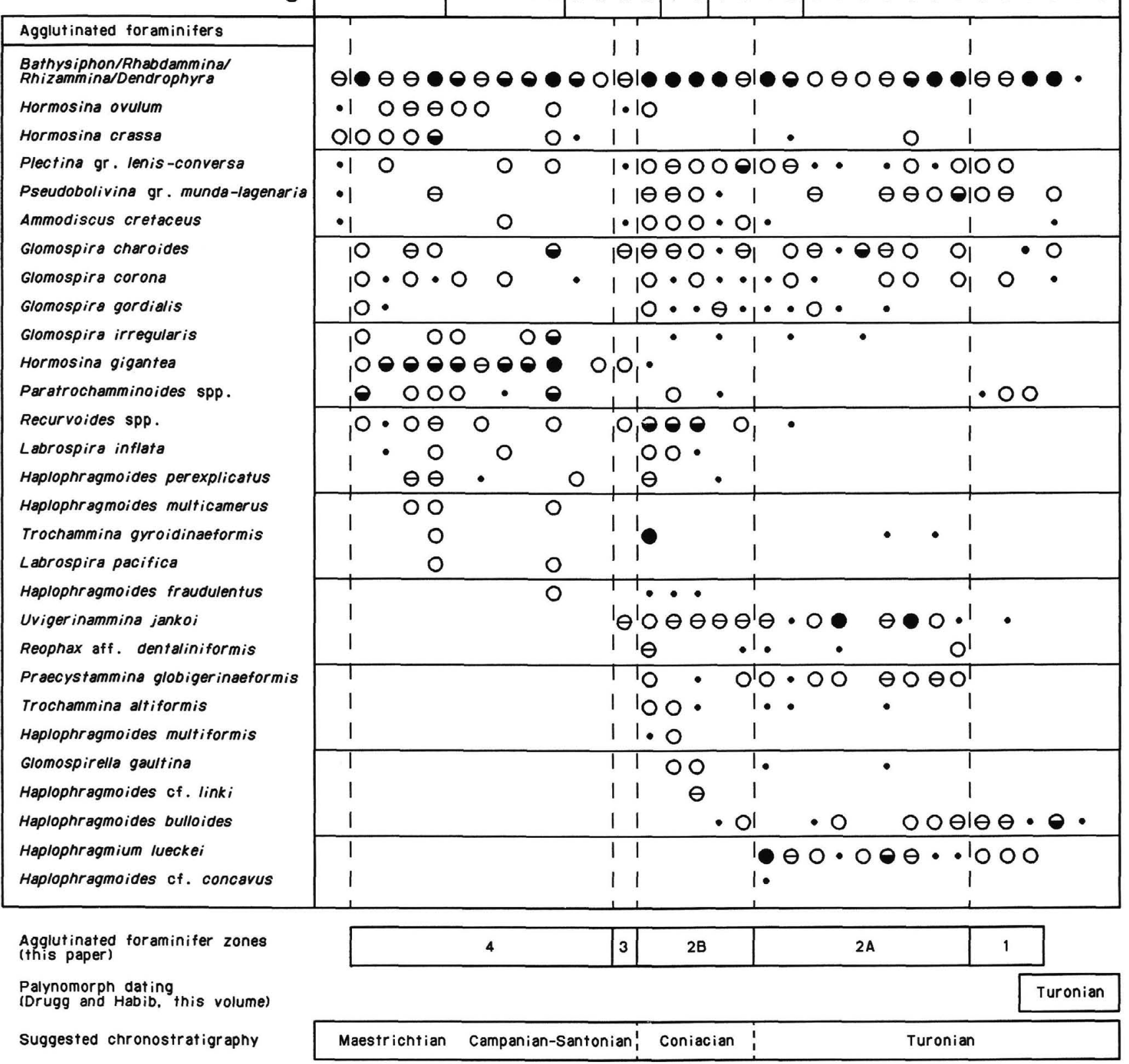

Figure 3. Distribution of Upper Cretaceous agglutinated benthic foraminifers, Hole 641A. 


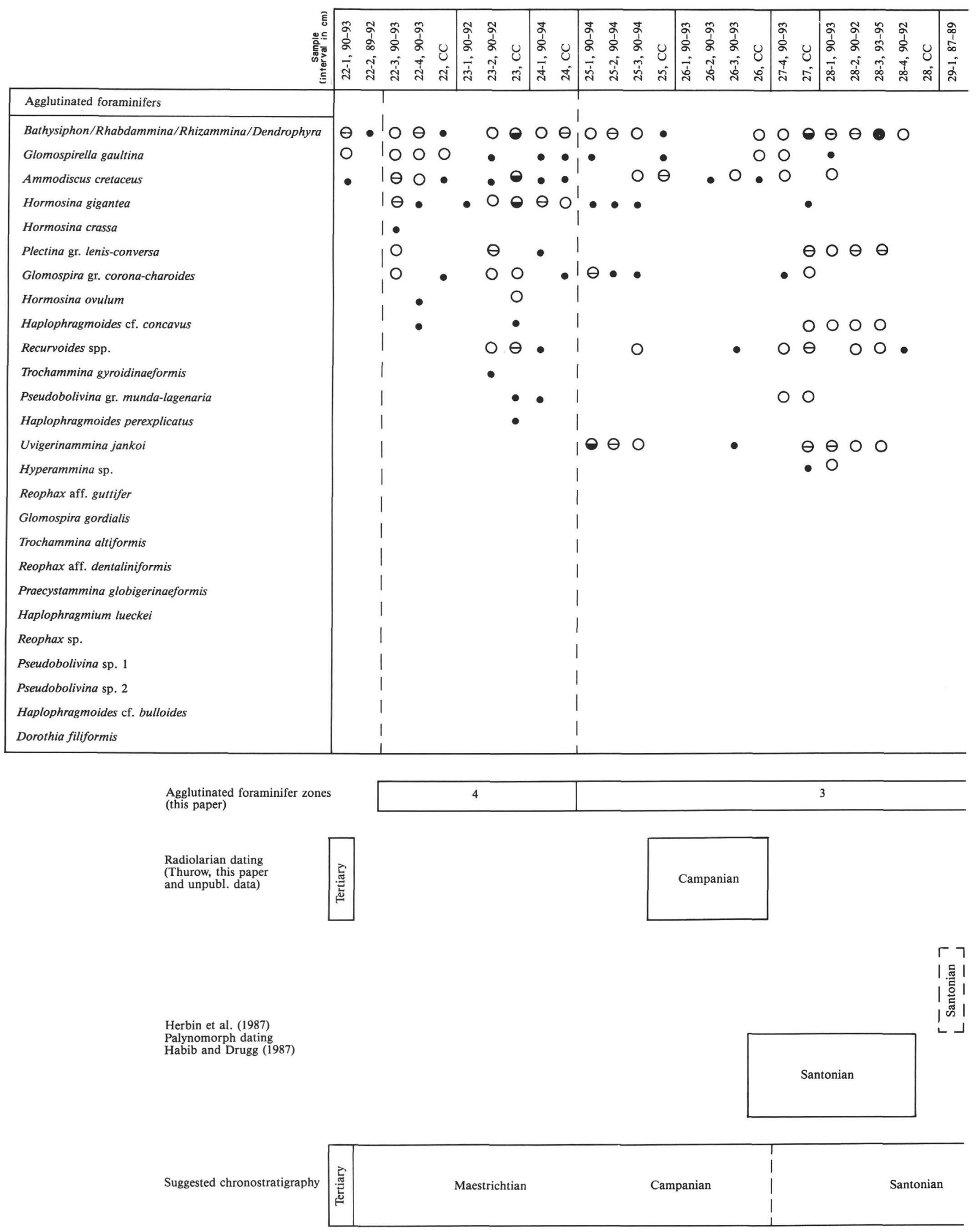

Figure 4. Distribution of Upper Cretaceous agglutinated benthic foraminifers, Hole 603B. 


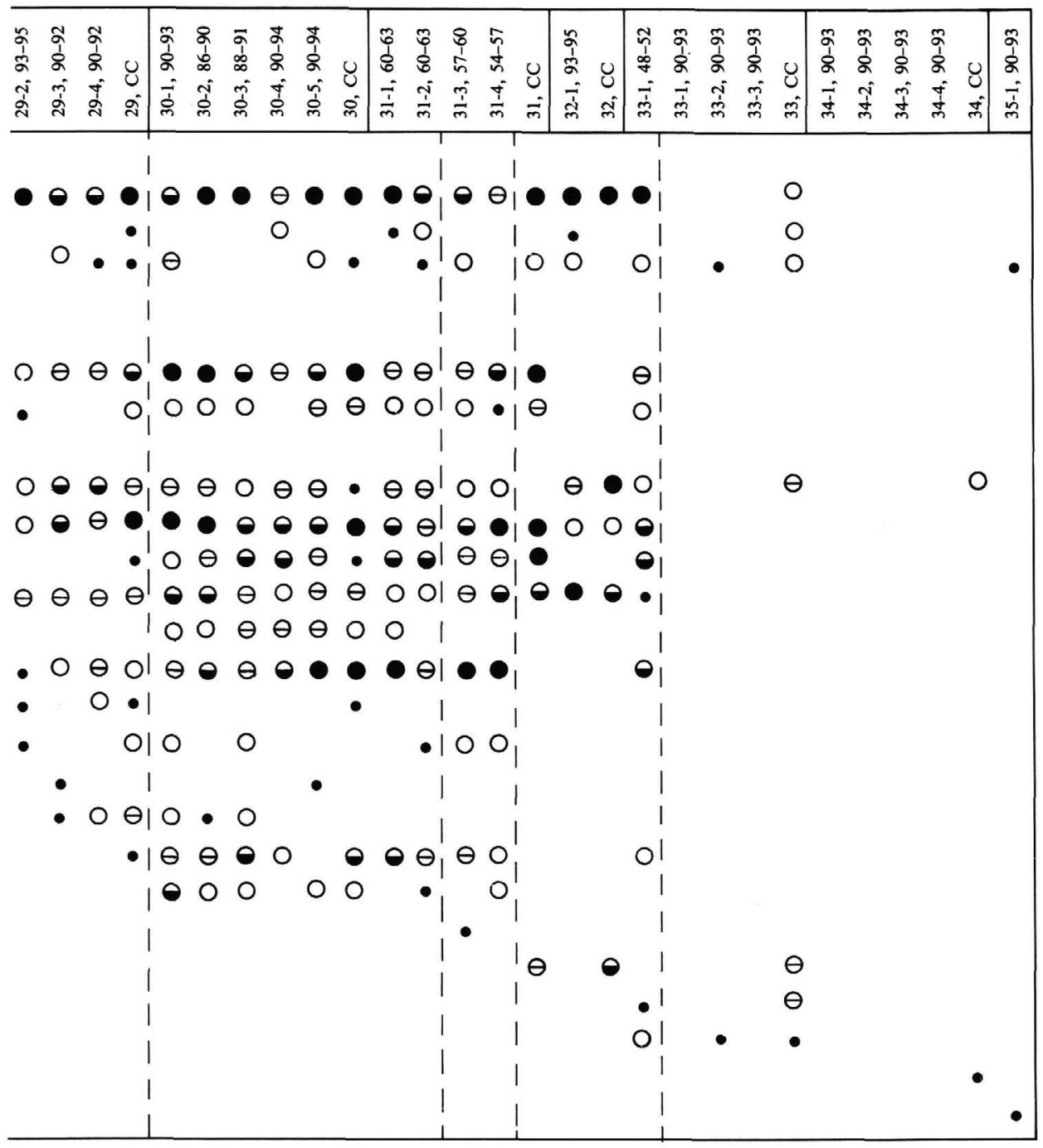

Symbols

- Very rare (1 specimen per sample)

$\begin{array}{ll}\ominus & \text { Rare (1-3) } \\ \ominus & \text { Few }( \pm 5)\end{array}$

Common $(>10)$

Abundant $(>50)$

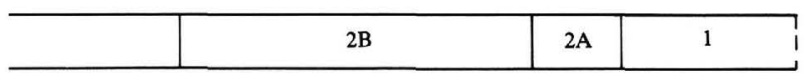

Turonian
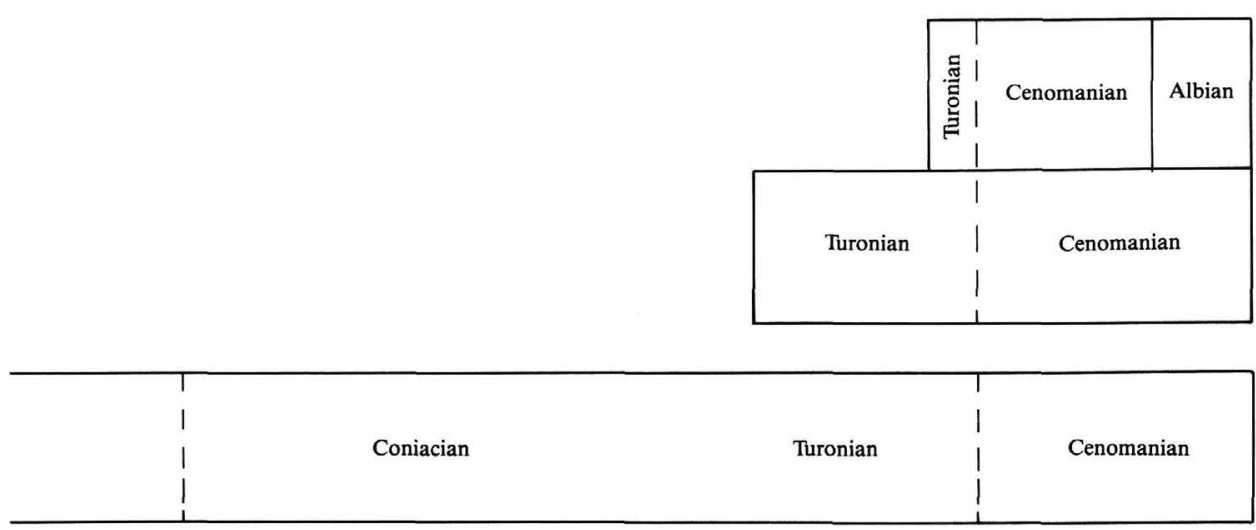

Figure 4 (continued). 
contaminants are much less frequent; rare specimens are found only in three samples.

As far as biostratigraphic markers are concerned, $P$. globigerinaeformis, $U$. jankoi and $H$. gigantea show a stratigraphic distribution and succession that compare well with that observed in Hole 641 A, but $H$. lueckei only occurs in one sample (603B$31-3,57-60 \mathrm{~cm}$ ). Taking the position of the datums given by the distribution of the three other markers into account, it appears that this sample might coincide with the extinction level depicted for this species in Hole 641A. Among the additional stratigraphically significant species found in Hole 641A, only $R$. sp. aff. dentaliniformis, $T$. altiformis, and $H$, perexplicatus are sufficiently well represented to be considered as having similar ranges in both holes.

\section{Hole $640 \mathrm{~A}$}

Upper Cretaceous agglutinated foraminifers are found only in the brownish clays from Samples 103-640A-2R-2, 30-32 cm, to $103-640 \mathrm{~A}-2 \mathrm{R}-1,42-46 \mathrm{~cm}$ (i.e., in an interval about $1.35 \mathrm{~m}$ thick) (Fig. 5). Most of the studied samples contain a low-diversity assemblage dominated by Bathysiphon-like specimens, Hormosina, and a few Recurvoides. H. gigantea is found throughout this interval.

\section{Zonal Scheme}

Comparison of Figures 3 through 5 shows that the stratigraphic distribution of several species, regarded as markers, appears to be similar in the Upper Cretaceous beds drilled on both sides of the North Atlantic. As a result, the following "regional" zonal subdivision is proposed (Fig. 6):

\section{Zone 1: Haplophragmium lueckei Zone}

The lower boundary of the $H$. lueckei partial range Zone is defined by the first appearance datum (FAD) of the index species (this datum also coincides with the FAD of $U$. jankol). Its upper boundary is the lower boundary of the following zone.

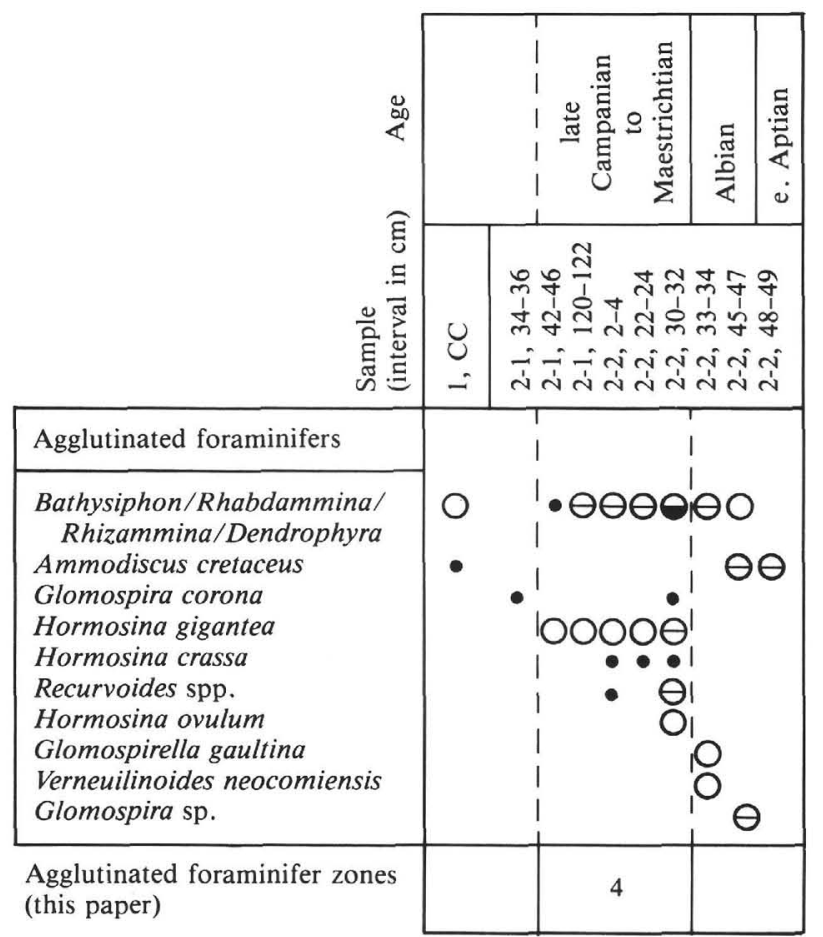

Figure 5. Distribution of Upper Cretaceous agglutinated benthic foraminifers, Hole 640A.

\section{Zone 2: Praecystammina globigerinaeformis Zone}

The lower and upper boundaries of this total range zone are respectively defined by the lowest and highest occurrences of the marker species. This zone can be subdivided in two parts, a lower subzone $2 \mathrm{~A}$ characterized by the concomitant occurrence of $H$. lueckei and $P$. globigerinaeformis, and an upper subzone 2B defined by the co-occurrence of the zonal marker and $H$. perexplicatus (the latter is too scarcely distributed to be used at the zonal level).

\section{Zone 3: Uvigerinammina jankoi Zone}

This partial range zone has a lower boundary that coincides with the upper boundary of the preceding zone. The upper boundary is determined by the last appearance of the marker, a distinct event at both Sites 603 and 641 .

\section{Zone 4: Hormosina gigantea Zone}

The lower boundary of the $\boldsymbol{H}$. gigantea partial range Zone is defined by the upper boundary of the $U$. jankoi Zone. The upper boundary is at the level extinction (at the three studied sites) of the marker.

\section{Attempted Calibration}

\section{Calibration in the Three Studied North Atlantic Holes}

\section{Radiolarians}

Radiolarians were studied from Upper Cretaceous black shales and variegated claystones from Holes 603B and 641A (the brown manganiferous clays from Hole 640A are devoid of these organisms).

Samples with abundant radiolarians are found only in Hole 603B, where they are predominantly concentrated in two intervals: (1) in the greenish claystones directly above the black shales of the upper part of the Hatteras Formation (approximately Core 603B-33) and (2) in the variegated claystones of the Plantagenet Formation (approximately Core 603B-26). The preservation did not allow a statistical evaluation of the fauna, although most of the recovered specimens were sufficiently well preserved to refine the biostratigraphy and to permit discussion of the paleoceanographic significance of these radiolarian-rich intervals.

Hole 641. Only two samples (103-641A-4X-1, 48-52 cm, and $103-641 \mathrm{~A}-6 \mathrm{X}, \mathrm{CC}[21-24 \mathrm{~cm}])$ contain rare and poorly preserved radiolarians. The two species occurring in the first sample are Sethocapsa cf. simplex and a nassellarian that is generally named Stichomitra communis. S. cf. simplex is recorded from the upper Albian to the top of the Turonian in Japan (Taketani, 1982) and from the Albian of Vigo Seamount (DSDP Hole 398D; see Thurow, this volume), and $S$. communis is common in the Turonian sediments of southern Europe and northwestern Africa (Squinabol, 1903; Kuhnt et al., 1986). As the stratigraphic ranges of these two forms are not yet well established, the age given by these radiolarians remains uncertain.

In Sample 103-641A-6X, CC (21-24 cm) (black shale) we found a zeolitized, and therefore doubtful, Alievium sp. with a domed, pillowlike shape. Such forms have their first occurrence approximately at the base of the Turonian.

Hole $603 \mathrm{~B}$. The first radiolarian-rich interval consists of reddish/brownish zeolitic claystones and includes Section 603B25, CC, Samples 603B-26-1, 90-93 cm, 603B-26-2, 90-93 cm, 603B-26-3, 90-93 cm, and Section 603B-26, CC. Radiolarians are common to abundant and generally poorly preserved, with diagenetic transformation into clinoptilolite. However, all of the samples contain $\left(<1 \%\right.$ per $\left.10 \mathrm{~cm}^{3}\right)$ moderately to well-preserved specimens. Not all the taxa are formally described in the current literature, but many of them, especially the nassellarians, have been mentioned by other authors (Pessagno, 1963, 1976; Dumi- 


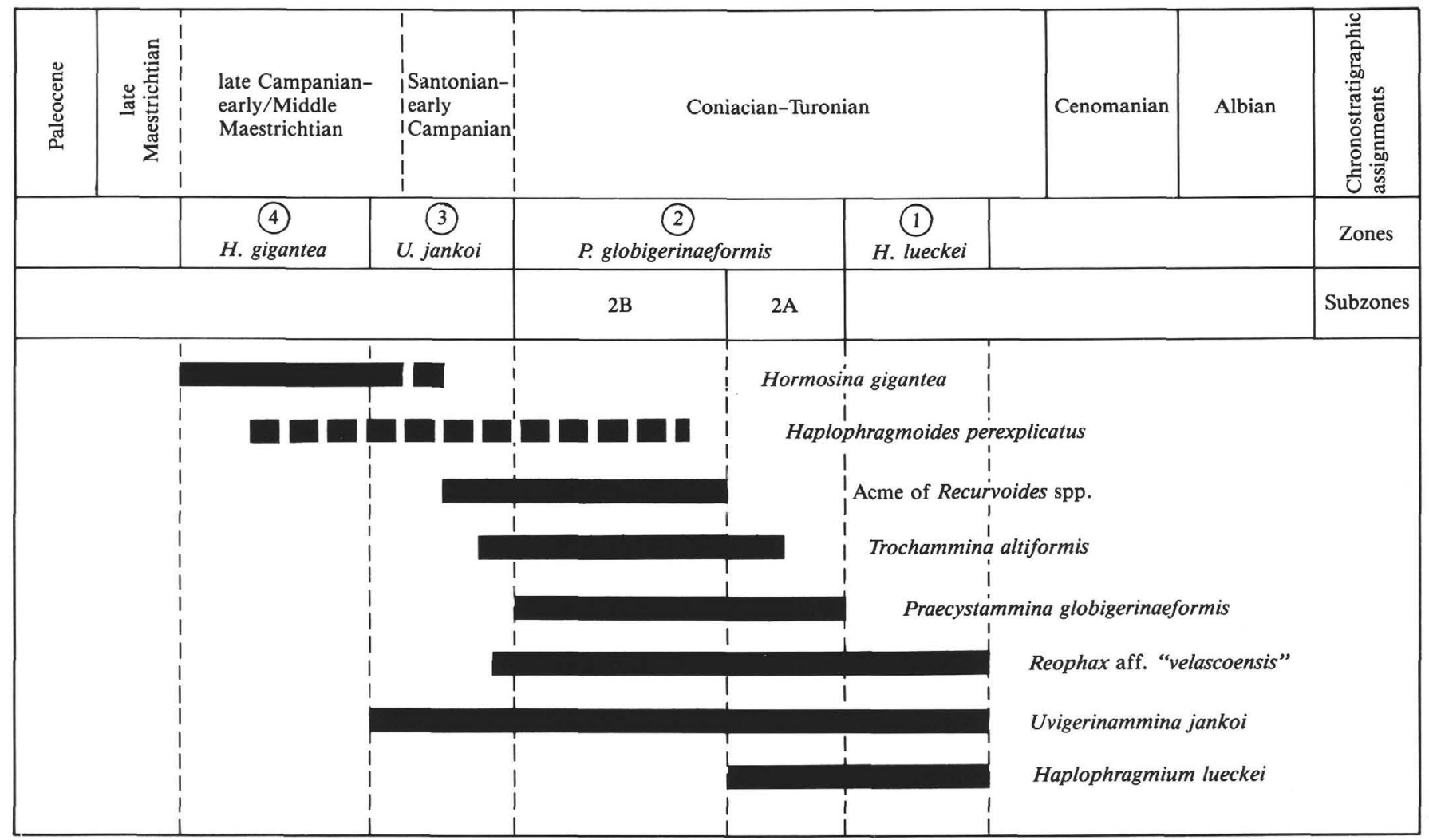

Figure 6. Zonal scheme based on the distribution of the main agglutinated foraminiferal marker species.

trica, 1970; Foreman, 1971, 1978; Riedel and Sanfilippo, 1974; Butt, 1981; Empson-Morin, 1981, 1984; Taketani, 1982) in coeval strata. Some reliable stratigraphic markers can be discriminated. The most abundant forms belong to the genera Dictyomitra (Dictyomitra formosa and Dictyomitra koslovae), Alievium (Alievium gallowayi), and Pseudoaulophacus (Pseudoaulophacus floresensis, Pseudoaulophacus lenticulatus, and Pseudoaulophacus pargueraensis); other important stratigraphic forms are Afens liriodes, Amphipyndax cf. pseudoconulus, Archaeodictyomitra lamellicostata, Clathropyrgus titthium, Theocampe tina, and Patulibracchium californiaensis (Fig. 7).

Upper Cretaceous sections that are continuously radiolarian bearing are rare; thus, the stratigraphic ranges of Upper Cretaceous species are not well established. According to most accepted range charts, a Campanian (most probably early to middle Campanian) age is suggested for the preceding radiolarian assemblage.

Sample 603B-33-1, 38-42 cm, taken from a coarse sandstone that marks an important change in sedimentation at Hole 603B, contains rare and poorly preserved zeolitic radiolarians. Taxa including $A$. liriodes, Alievium sp., Crucella sp. with a large lacuna in the central part, Patellula sp., and some poorly preserved Dictyomitra spp. can be identified. The occurrence of $A$. liriodes would indicate a Campanian age (Moore, 1973; Riedel and Sanfilippo, 1974; Nakaseko and Nishimura, 1981; Kling, 1982), but Sanfilippo and Riedel (1985) recently reported this form from Turonian strata in northern Italy. Crucella sp. with a large lacuna might be either Crucella cachensis (Turonian) or Crucella espartoensis (Santonian/Campanian). The other forms are not age significant. Therefore, at the present state of the stratigraphic knowledge, a Turonian age seems probable for Sample $603 \mathrm{~B}-33-1,38-42 \mathrm{~cm}$.
A second radiolarian-rich interval occurs in Core 603B-33R. Samples 603B-33-1, 90-93 cm, 603B-33-2, 90-93 cm, and 603B$33-3,90-93 \mathrm{~cm}$, contain common to abundant, poorly to moderately preserved zeolitic radiolarians (Fig. 7). The most characteristic forms are $C$. cachensis (a variety with an elevated and prominent central part that characterizes the deeper part of the range of this species), Alievium superbum, Pseudoaulophacus putahensis, Cavaspongia antelopensis, Cavaspongia californiaensis, Pyramispongia glascockensis, Dumitricaia maxwellensis, Pseudodictyomitra nakasekoi, and Pseudodictyomitra pseudomacrocephala. This assemblage includes most of the forms described as the typical radiolarian association (Thurow et al., 1982; Kuhnt et al., 1986; Thurow and Kuhnt, 1986; Thurow, 1987) of the almost global Cenomanian/Turonian Boundary Event (CTBE) (Arthur et al., 1986; Herbin et al., 1986; Schlanger, 1986; for additional data, see also Thurow et al., this volume).

Sample 603B-33, CC, (greenish claystone) and Cores 603B34 and 603B-35 (black shales) contain rare to common, generally poor but also some moderately preserved radiolarians. Most of the specimens are not identifiable even at a generic level, but some rare forms can be identified, even specifically. Two samples taken from the black shale interval (Samples 603B-34-3, 90-93 cm, and 603B-35-1, 90-93 cm) contain only a few age-diagnostic forms, as does the sample from Section 603B-33, CC, at the transition from the black shale to the overlying greenish claystone. In Sample 603B-34-3, 90-93 cm, Holocryptocanium aff. barbui, Conocaryomma aff. universa, $P$. glascockensis, $P$. putahensis, and Patellula sp. can be distinguished. $P$. putahensis is not recorded from strata older than early Turonian.

Atlantic Ocean radiolarians are known to be not as abundant or as well preserved as in the Pacific. This suggests that the poor preservation of siliceous skeletons might be due to the rela- 


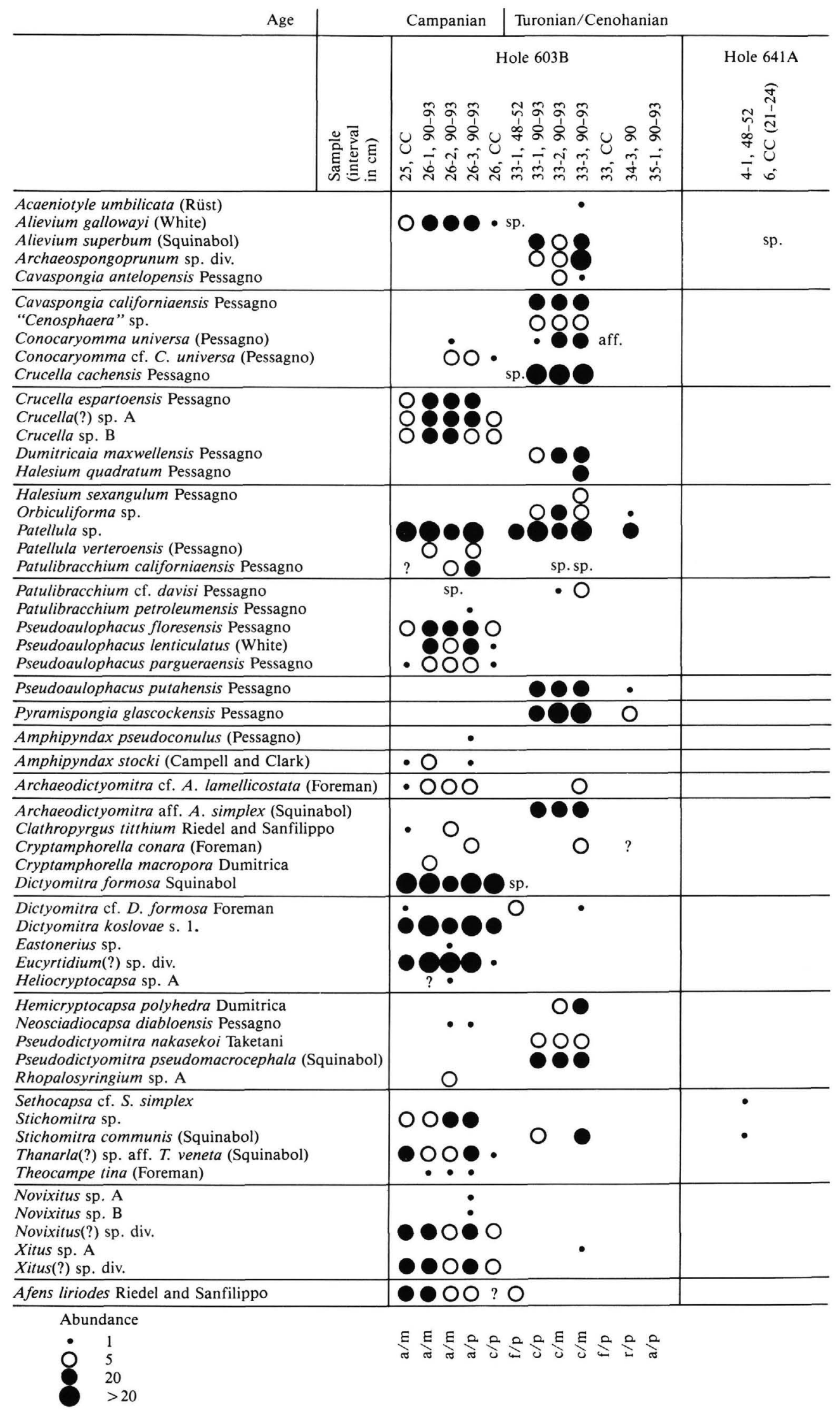

Figure 7. Distribution of Upper Cretaceous radiolarians, Holes 603B and 641A. Sample 603B-34-3, $90 \mathrm{~cm}$, has opaline preservation; Sample 603B-35-1, 90-93 cm, has preservation in pyrite/quartz. 
tively small amount of silica deposited in the Atlantic Ocean sediments. Examination of the Mesozoic cores from Hole 603B on the northwestern Atlantic margin confirms this assumption. However, there are two remarkable exceptions in the Upper Cretaceous section, in which two short intervals with radiolarianrich deposits are identified. These radiolarian "blooms" are widespread (even recorded into marginal seas) and can be regarded as special and synchronous geological events.

The younger event is well documented in Hole 603B and coincides with a worldwide, brief period of radiolarian-rich (or at least siliceous-rich) deposition during the Campanian that is found in various tectonic settings (Japan, Cyprus, Gibraltar Arch area, and Eastern Alps). Such a biosiliceous event is most easily detected in pelagic or autochthonous layers in flysch-type deposits, probably as a result of a low dilution of the radiolarian layers with detrital material, as recorded by several authors (see compilations in Empson-Morin, 1984; Iwata and Tajika, 1986). In the Eastern Alps (within the Gosau Basin, close to Bad Reichenhall, Northern Calcareous Alps, Bavaria) a brief peak of radiolarian-rich deposition was reported in the Campanian (Herm, 1962; Butt, 1981; Empson-Morin, 1984), with assemblages having numerous taxa in common with those found in Hole 603B (Thurow, this volume). Calibration with planktonic foraminifers of the zones rich in radiolarians in layers that comprise the Globotruncana elevata Zone, directly below the first occurrence of Globotruncana calcarata (Butt, 1981), result in an early to middle Campanian age for the radiolarian bloom and consequently, for Core 603B-26.

\section{Palynomorphs}

Hole 603B. Habib and Drugg (1987) and Herbin et al. (1987) studied palynomorphs (chiefly dinoflagellates) occurring in several discontinuous intervals in the Upper Cretaceous section of Hole 603B. According to Herbin et al. (1987), the Albian/Cenomanian boundary occurs in Section 603B-34-5, and the Cenomanian and Turonian stages are very condensed, as they are contained in a short interval from the remaining upper part of Core 603B-34 and the bottom of Core 603B-33. Habib and Drugg (1987) report a late Coniacian to early Santonian age palynomorph assemblage in Core 603B-28 up to the bottom of Core 603B-26, and Herbin et al. (1987) give a Santonian age to the rich and diverse microplankton assemblage found in Sample 603B-29R, 57-62 cm.

Hole 641A. According to Drugg and Habib (this volume), the black organic-carbon-rich clay interval from the lowermost part of Core 103-641A-6X contains Cenomanian-Turonian pollens and (in Sample 103-641A-6X, CC [34-35 cm]) dinoflagellates that indicate an age not older than Turonian. As a result, the uppermost studied fossiliferous (for palynomorphs) sample (103-641A-6X-7, 24-25 cm), in which the agglutinated foraminifer $H$. lueckei first appears, is also Turonian.

\section{Ichthyoliths}

At the time of writing of this paper, results dealing with ichthyolith stratigraphy were available only for Hole 640A. According to P. Doyle (pers. comm., 1987) the Cretaceous/Tertiary boundary in this hole occurs in Section 103-640A-2R-1, between 84 and $103 \mathrm{~cm}$, but several Cretaceous forms are present in the overlying lower Paleocene section, indicating sediment mixing across the boundary.

\section{Magnetostratigraphy}

Hole $603 \mathrm{~B}$. No paleomagnetic measurements were made on the Upper Cretaceous sediments of Hole 603B.

Hole 640A. According to shipboard investigations (Boillot, Winterer, et al., 1987), the sampling for paleomagnetic investi- gations was inadequate for this hole as a result of the strong sedimentary condensation.

Hole 641A. Thirty-eight minicores of Upper Cretaceous brown clay and greenish gray calcareous clay were studied for paleomagnetic data, the results of which (Ogg, this volume) are shown in Figure 8. Control is poor from Cores 103-641A-3X to 103-641A-7X because sampling was not sufficiently dense in a relatively condensed series and/or from low core recovery. However, it appears that the lower part of this sequence (i.e., Core 103-641A-7X and the lower part of Core 103-641A-6X) belongs to the Cretaceous (Aptian to Santonian) long normal polarity interval. The section including the upper part of Core 103641A-6X and Cores 103-641A-5X and 103-641A-4X is paleomagnetically uncertain; based on its presumed age, this part should logically belong to the same long normal interval, but it includes at least two samples with a reverse polarity. Better information is obtained in Core 103-641A-3X, which could correspond to the normal late Campanian Chron 33, and in Core 103-641A-1X, which shows two clear normal polarity intervals separated by a short reversal, a pattern that evokes the Maestrichtian (Chrons 31-32?). Nevertheless, the rough and questionable delineation of part of the Campanian and Maestrichtian patterns in the upper part of the hole limits its application to resolving the calibration.

\section{Calibration by Means of Comparable Facies and Assemblages}

\section{Agglutinated Foraminifers from Flysch-type Assemblages in the Gibraltar Arch Area}

A comparison was made with the stratigraphic distribution of partially similar foraminiferal assemblages from outcrops in the Gibraltar Arch area. Within these bathyal and abyssal series, four characteristic assemblages of agglutinated foraminifers were distinguished (Kuhnt, 1987):

1. An assemblage defined by the occurrence of Hippocrepina depressa; other characteristic forms are Dorothia filiformis and Pseudobolivina variabilis. This fauna is found in the first pelitic formation overlying the Aptian to middle Albian siliciclastic turbidite sequence and below the "phtanites," which are the local expression of the CTBE (Thurow and Kuhnt, 1986).

2. An assemblage defined by the occurrence of $U$. jankoi. Other characteristic forms are Hyperammina excelsa and $\mathrm{Hy}$ perammina elongata; the first occurrence of the genus Paratrochamminoides is also observed. This zone corresponds to the second pelitic formation, which has a late Turonian to Santonian age (based on palynomorphs; J. Thurow, P. Hochuli, and W. Kuhnt, unpubl. data, 1986).

3. An assemblage defined by the first occurrence and maximum in abundance of Hormosina gigantea. Additional characteristic forms include Rzehakina epigona and Rzehakina fissistoma. This zone corresponds to a calciturbidite and hemipelagite sequence in which a correlation by means of planktonic foraminifers is possible; beds with $\boldsymbol{H}$. gigantea are thus given a middle Campanian (Globotruncana ventricosa Zone) to middle Maestrichtian (Globotruncana gansseri Zone) age.

4. An assemblage defined by the extremely rare occurrence or absence of $H$. gigantea; characteristic forms include various species of the genus Paratrochamminoides. The age of this assemblage is middle/late Maestrichtian to Paleocene.

Most of the flysch-type agglutinated assemblages from the Gibraltar Arch area differ from those found in the brown clays of Sites 603 and 641 because of the different paleoenvironmental context (shallower water depth, higher detrital input, and usually oxygen-depleted bottom conditions). Nevertheless, some species of stratigraphic value occur in both provinces. In the Gi- 


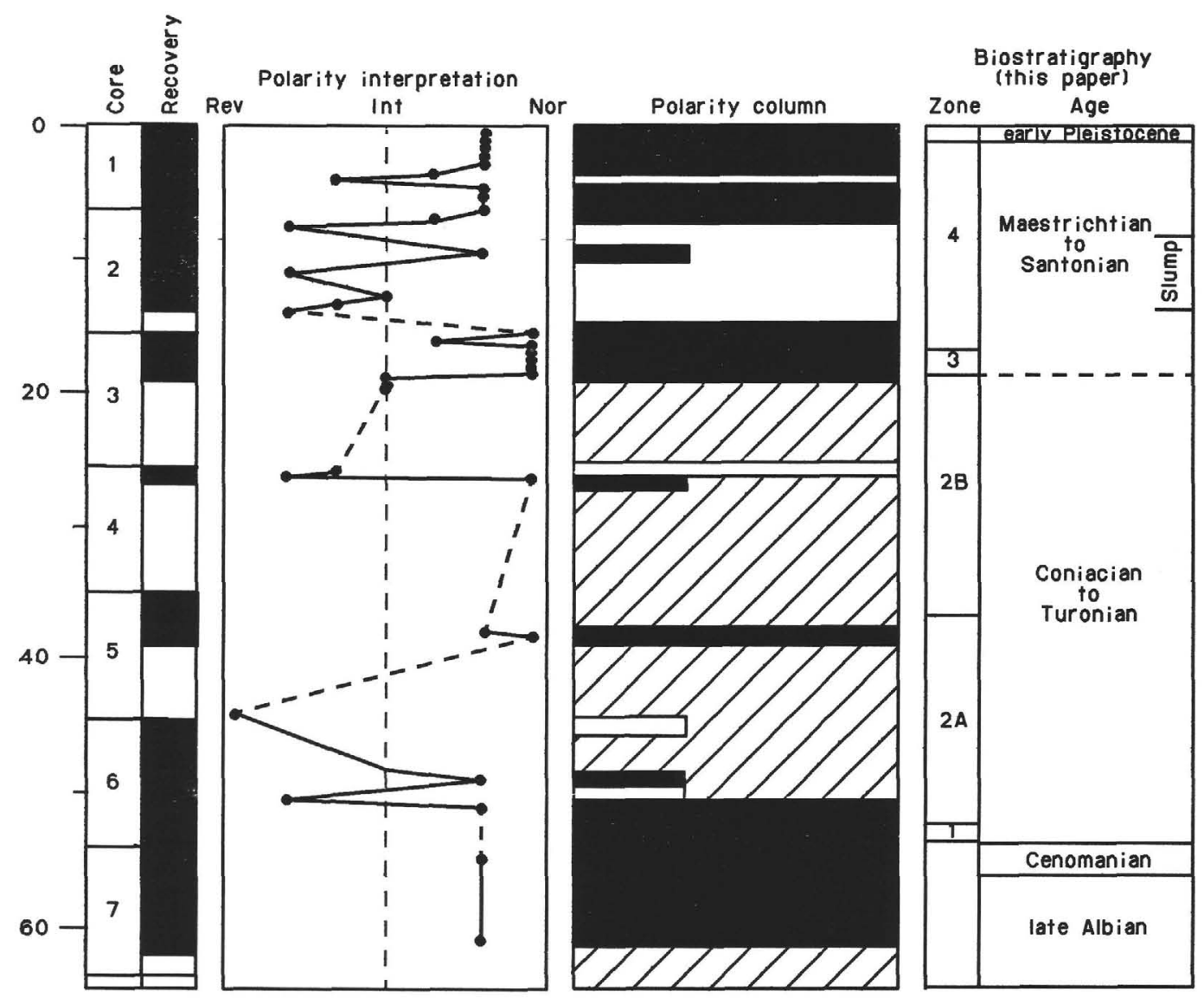

Figure 8. Comparative magnetostratigraphy (after Ogg, this volume) and biostratigraphy (based on agglutinated foraminifers) of Hole 641A.

braltar Arch area it is possible to directly calibrate their distribution by means of other fossil groups, such as palynomorphs, planktonic foraminifers (autochthonous and redeposited), and radiolarians:

$U$. jankoi: First appearance at the base of the second pelitic formation (middle/upper Turonian), abundant in the Coniacian/ Santonian (middle and upper part of the second pelitic formation); never observed in middle to upper Campanian or Maestrichtian sequences.

$H$. gigantea: First appearance in the middle Campanian $(G$. ventricosa Zone), maximum of abundance in the upper Campanian-lower Maestrichtian; absent in the upper Maestrichtian.

Paratrochamminoides spp.: characteristic of the second pelitic formation and younger strata, with a first appearance in the Turonian. A general trend to a maximum in diversity and abundance toward the Maestrichtian is observed.

\section{Agglutinated Foraminifers from Deep-Water Limestones of the Western Mediterranean (Betic Cordillera, Spain, and Umbrian Appenines, Italy)}

In order to better calibrate the stratigraphic distribution of deep-water agglutinated foraminifers, a study of Turonian to lower Paleocene beds of a section near Ronda (Penibetic) and the Gubbio section (Umbrian Appenines) is in progress by W. Kuhnt. $\mathrm{HCl}$ residues from the Penibetic and the two road sections near Gubbio (Contessa and Bottaccione sections), which are the most famous biostratigraphic and magnetostratigraphic standard sections for the Tethyan Upper Cretaceous, consist almost completely of flysch-type agglutinated foraminifers. A preliminary study of the stratigraphic distribution of these forms led to the following:
1. The lower part of the sections (from lower Turonian to lower Coniacian) contains only rare and low-diversity agglutinated assemblages (mainly indeterminate tubes and species of the family Ammodiscidae). Radiolarians and (secondarily) silicified planktonic foraminifers are common in the $\mathrm{HCl}$ residues.

2. The first important assemblage of agglutinated foraminifers characterizes the Coniacian and Santonian. Among them, $U$. jankoi occurs, with a first appearance as early as the late Turonian in the Penibetic section.

3. A distinct change in the faunal composition is observed in the lower Campanian. The second association is thus characterized by frequent Spiroplectammina. U. jankoi is absent and $H$. gigantea occurs (very rarely in the Campanian of the Penibetic section) as well as $R$. gr. epigona and Nodellum velascoense.

This distribution pattern of agglutinated marker species can be compared to that of the assemblages found in the variegated clays of the Plantagenet Formation and flysch-type assemblages of the Gibraltar Arch area. A fairly similar striking change appears in the composition of faunal assemblages in the lower Campanian. The main feature is the last appearance datum (LAD) of $U$. jankoi, followed by the radiation of several groups, including the first occurrence of the marker species $H$. gigantea.

\section{DISCUSSION AND COMPARISON WITH OTHER OCEANIC OR FLYSCH OCCURRENCES}

\section{Pacific Ocean}

Agglutinated benthic foraminifers were studied by Krashenninikov (1973) from dark brown and reddish yellow zeolitic and silty clays drilled at Holes 196 and 198A (DSDP Leg 20) in the 
northwestern Pacific Ocean, from $25^{\circ}$ to $30^{\circ} \mathrm{N}$ and water depths close to $6000 \mathrm{~m}$. The author noted the small size of the extremely thin-walled oceanic specimens, which differentiated them from contemporaneous and generally morphologically similar agglutinates found in flysch facies cropping out onshore. These assemblages appear to have a low diversity and are composed almost entirely of new species. According to Foreman (1973), some accompanying radiolarians suggest a probable early Campanian age for the beds bearing agglutinated foraminifers. No range chart was given for foraminifers. However, simultaneous occurrences of taxa including Haplophragmoides perexplicatus, P. globigerinaeformis, and several species of the genus Paratrochamminoides lead us to suggest that these assemblages first described by Krashenninikov are contemporaneous with the microfauna defining our subzone $2 \mathrm{~B}$.

\section{Indian Ocean}

Upper Cretaceous brown zeolitic clays were penetrated in low southern latitudes $\left(13^{\circ}\right.$ to $16^{\circ} \mathrm{S}$ ) at Sites 260 and 261 (water depth close to $5700 \mathrm{~m}$ ) on DSDP Leg 27 in the northeastern Indian Ocean off northwestern Australia (Gascoyne and Argo abyssal plains) (Veevers, Heirtzler, et al., 1974). As in the Pacific, such sediments are devoid of an in-situ calcareous microfauna but contain relatively rich, well-preserved and highly diverse agglutinated benthic foraminiferal assemblages, which were also studied by Krashenninikov (1974). Of the 44 identified species, 16 were new, 12 were previously first described by the same author from the Pacific Ocean, and 16 others were previously known from dominantly flysch or flysch-type deposits. One assemblage characterized by $P$. globigerinaeformis found at both Indian Ocean sites was thought to be identical to that described from the Northwest Pacific. On the basis of a mixed accompanying fauna of Albian to Coniacian planktonic foraminifers that was found in one sample at the top of the beds with $P$. globigerinaeformis, the agglutinated assemblage was given an age not older than late Turonian/Coniacian by Krashenninikov (1974). At Site 261, the $P$. globigerinaeformis assemblage is underlain by a slightly different association, characterized by $H$. lueckei.

A careful examination of the range chart for the two sites (Krashenninikov, 1974) shows that the upper assemblage reasonably compares with our subzone $2 \mathrm{~B}$, and the lower assemblage compares to our zone 1 . Subzone $2 \mathrm{~A}$, defined in our material by the co-occurrence of $H$. lueckei and $P$. globigerinaeformis, does not seem to be present (hiatus?) at Site 261 .

\section{Atlantic Ocean}

\section{DSDP Leg 41 (Eastern North Atlantic, Cape Verde Basin and Rise)}

Hole $367\left(12^{\circ} 30^{\prime} \mathrm{N}\right.$; water depth $\left.4750 \mathrm{~m}\right)$ penetrated $220 \mathrm{~m}$ of Upper Cretaceous multicolored silty clays from which only two cores were taken. Krashenninikov and Pflaumann (1977) produced a faunal list of the agglutinated benthic foraminifers, among which are $U$. jankoi, Hormosina ovulum, Recurvoides spp., and Paratrochamminoides spp. In one core, these forms were found with Coniacian-Maestrichtian nannofossils. Hole $368\left(17^{\circ} 30^{\prime} \mathrm{N}\right.$; water depth $\left.3370 \mathrm{~m}\right)$ drilled and spot cored a thick pile of Upper Cretaceous sediments, composed of (1) Cenomanian-Turonian black shales (containing $U$. jankoi and $P$. conversa), (2) multicolored clays ( $80 \mathrm{~m}$ thick), and (3) green clays ( $140 \mathrm{~m}$ thick). Formations 2 and 3 provided the same mentioned agglutinated forms, plus, in formation 3 only, various subspecies of the $R$. epigona group (known to range up to the Paleocene). This multicolored and green clay sequence was attributed by Krashenninikov and Pflaumann (1977) to the Upper Cretaceous, and, in particular, formation 3 to the uppermost Cretaceous (Campanian-Maestrichtian), rather than to the $\mathrm{Pa}$ - leocene, on the basis of the co-occurrence of scarce Cretaceous radiolarians with foraminifers. Thus, no precise biostratigraphic information can be obtained from these two holes, which reveal that a $U$. jankoi-P. conversa assemblage appearing as early as the Cenomanian-Turonian underlies a CampanianMaestrichtian $R$. epigona s.l. assemblage.

\section{DSDP Leg 43 (Northwest Atlantic, North and West of the Bermuda Islands)}

Varicolored or red clays were drilled at two sites during DSDP Leg 43 (Site $385: 37^{\circ} \mathrm{N}$; water depth $4950 \mathrm{~m}$; Site $387: 32^{\circ} \mathrm{N}$, water depth $5120 \mathrm{~m}$ ) and yielded scarce and tiny agglutinated benthic foraminifers. McNulty (1979) included global faunal lists in his paper devoted to the Cretaceous foraminifers from this leg and, as far as Upper Cretaceous is concerned, noted that "the fauna is composed... of agglutinated forms... such as those described by Krashenninikov." The assemblage listed for Site 385 , which includes $P$. globigerinaeformis and $U$. jankoi, can be interpreted as not younger than early Campanian. However, McNulty (1979) mentioned the occurrence of an upper Maestrichtian (Abathomphalus mayaroensis Zone) planktonic foraminiferal fauna in a sample taken from somewhere in the middle of the agglutinated-bearing interval; this Maestrichtian sample was considered to be "redrilled cavings from uphole." At Site 387, red clays underlying a layer dated as Maestrichtian by means of nannofossils provided a few tiny agglutinated forms, including Hormosina sp. and Uvigerinammina sp., which possibly belongs to our zones 3 or 4 .

\section{DSDP Leg 47B (Vigo Seamount, West of the Iberian Peninsula)}

Hole $398 \mathrm{D}\left(41^{\circ} \mathrm{N}\right.$, water depth $\left.3910 \mathrm{~m}\right)$, about $160 \mathrm{~km}$ southsoutheast of Site 641 , penetrated a 175 -m-thick brown and red mudstone and claystone sequence above middle Cenomanian strata (Sibuet, Ryan, et al., 1979). The first 70 m contains only agglutinates, highly similar to those described by Krashenninikov $(1973,1974)$ from DSDP Legs 20 and 27, including as important forms $P$. globigerinaeformis, T. altiformis, Paratrochamminoides spp., Uvigerinammina sp. ( = zone 2, this paper), and attributed by Sigal (1979) to the Santonian. The overlying $100 \mathrm{~m}$ of the red sequence yielded, in addition to a scanty, primitive, and stratigraphically nonsignificant agglutinated assemblage, rich Campanian and Maestrichtian planktonic associations. Such a planktonic influx is lacking in the corresponding layers of nearby Hole 641A.

\section{DSDP Leg 75 (Angola Basin)}

McNulty (1984) mentioned a typical "brown clay" agglutinated foraminiferal assemblage in the Coniacian/Santonian of Hole 530A. The red and green claystones of Cores 530A-81 through 530A-86 contain a sparse fauna in which the author identified the following species (taxonomy partly revised by us);

\footnotetext{
Ammodiscus cretaceus (Reuss)

Bathysiphon sp.

Glomospira charoides (Parker and Jones)

Glomospira corona Cushman and Jarvis

?Glomospira multicarinata Krasheninnikov

Haplophragmoides coronatus (Brady)

Hormosina sp.

Hyperammina $\mathrm{sp}$.

Labrospira inflata Krasheninnikov

Paratrochamminoides sp.

Saccammina complanata (Franke)

Saccammina rhumbleri (Franke)

Praecystammina globigerinaeformis Krasheninnikov

Reophax sp.
} 
Trochammina sp.

Uvigerinammina jankoi Majzon

This is a typical assemblage of our $P$. globigerinaeformis Zone (2), more precisely subzone $2 \mathrm{~B}$.

Good calibration of this interval is possible owing to the cooccurrence of planktonic foraminifers at this site. According to McNulty's (1984) distribution charts, Core 530A-86 (at the base of the agglutinated foraminiferal interval) is Coniacian (Dicarinella concavata, Hedbergella flandrini, Marginotruncana marginata, Marginotruncana pseudolinneiana, Marginotruncana sinuosa, and Globotruncana fornicata). Cores 530A-81 and 530A82 contain rare planktonic species of Coniacian/Santonian age (D. concavata, $M$. sinuosa, and G. fornicata), and Cores 530A79 and 530A-80 (just above the agglutinates) are attributed to the lower Campanian (Dicarinella asymetrica, Globotruncana fornicata, Globotruncana arca, Globotruncana elevata, Globotruncana linneiana, Globotruncana stuartiformis, G. ventricosa, and Planoglobulina glabrata). Thus, these dates based on planktonics show that the equivalent of our subzone $2 \mathrm{~B}$ might not be older than Coniacian and not younger than early Campanian.

\section{DSDP Leg 78 A (Atlantic Abyssal Plain, East of Barbados Ridge)}

Hole $543 \mathrm{~A}\left(5630 \mathrm{~m} ; 15^{\circ} \mathrm{N}\right)$ recovered a 45 -m-thick brown and reddish claystone overlying basalt. This formation contains agglutinated foraminifers belonging to the Recurvoides association, as well as the Marssonella association, plus a quantitatively variable calcareous benthic component. From the range chart given by Hemleben and Troester (1984), it appears that $P$. globigerinaeformis, $H$. ovulum, and Hormosina crassa occur throughout this interval, with $H$. perexplicatus and $U$. jankoi only sporadically present in a few samples. We have shown previously that such fauna characterizes subzone $2 \mathrm{~B}$. In Hole 534A, rare nannofossils were found at two levels, indicating a possible Maestrichtian age for the top of the formation and an early Campanian age for its base.

This brief review of oceanic occurrences of agglutinated foraminifers shows that during the Late Cretaceous, approximately from the Turonian up to the Maestrichtian, a deep-water red beds facies was deposited worldwide, at least in low- and middle-latitudes, in the oceanic realm. The $P$. globigerinaeformis assemblage, first discovered by Krashenninikov (1973, 1974), that characterizes our zone 2 , is most commonly encountered. However, these oceanic data do not permit us to precisely chronostratigraphically constrain a zonation based on the distribution of deep-water agglutinated foraminifers. A better calibration approach would use the flysch-type record, particularly the intensively studied Carpathian area.

\section{Polish Carpathians}

Geroch and Nowak (1984) recently summarized, in the form of a zonation, most of the information dealing with the stratigraphic distribution of agglutinates collected during the last few decades in the Polish Outer Carpathians. In this area, these forms are sometimes found with ammonites, calcareous nannoplankton, and calcareous benthic and planktonic foraminifers, thus allowing precise calibration of the index species. For a direct comparison with the oceanic realm, we only retain the data concerning agglutinates belonging to the Recurvoides association. According to Geroch and Nowak (1984), the vertical range of $U$. jankoi spans the upper Turonian to the lower part of the upper Campanian, and $H$. gigantea is present in the upper Campanian, Maestrichtian, and Danian. There appears to be only a short concomitant occurrence of these two marker species (also depicted in our material from Holes 603B and 641A); this overlap corresponds to the lower part of the upper Campanian.

\section{CALIBRATION OF THE OCEANIC ZONAL SCHEME}

By combining of the various processes of direct calibration and the data extracted from the literature, we are able to propose a chronostratigraphic integration of our zonal scheme (Fig. 6) as follows:

Zone 1: definitely of Turonian age, possibly extending into part of the Coniacian. It is not clear (but probable) whether the lower boundary of this zone is within the late Turonian.

Zone 2: Coniacian pro parte maxima.

Zone 3: Santonian to the lower part of the late Campanian.

Zone 4: late Campanian (pro parte)-early/middle Maestrichtian.

Most of these age assignments must be considered tentative because of uncertainties in calibration and/or some degree of flexibility in agglutinated marker species stratigraphic ranges. For instance, the stratigraphic distribution of $P$. globigerinaeformis does not appear to be identical in the oceanic realm and in the Tethyan area (see the following). Such discrepancies might result from paleoenvironmental factors.

\section{REMARKS ON PALEOENVIRONMENT}

Two kinds of agglutinated foraminiferal assemblages, which differ in abundance, preservation, diversity, and taxonomic composition, are observed in both Holes 603B and 641A:

1. Well-preserved, highly diversified assemblages, consisting of specimens having a brownish siliceous agglutinated wall. Characteristic of these assemblages are tiny, smooth-walled species of the genera Labrospira, Haplophragmoides, and Pseudobolivina. Additional forms include (among others) $H$. lueckei, $U$. jankoi, Hormosina spp., Plectina spp., and Trochammina spp.

2. Impoverished assemblages, commonly composed of compressed specimens showing a generally whitish agglutinated wall. Typical components of these types of assemblages are various species of Ammodiscus, Glomospira, and Glomospirella, and tube-shaped forms of the Rhizammina/Rhabdammina/Dendrophrya complex. Uvigerinammina, Hormosina, Haplophragmoides concavus, Recurvoides spp., Plectina, and Paratrochamminoides also occur. All of these forms are more characteristic of the A-type (flysch-type) assemblage, as defined by Gradstein and Berggren (1981).

In the two studied holes, these two assemblages show a characteristic distribution pattern. Assemblage 1 is associated with the typical brown zeolitic clay facies. In Hole 641A, it occurs continuously upsection, above Sample 103-641A-6X-7, 15-18 $\mathrm{cm}$. In Hole 603B, it occurs in an interval from Samples 603B$33-1,48-42 \mathrm{~cm}$, to $603 \mathrm{~B}-27-2,90-93 \mathrm{~cm}$, and again in Cores 603B-24 and 603B-23R. The brownish color of the corresponding sediments and the low values of total organic carbon measured in these intervals suggest that these highly diversified assemblages lived in a well-oxygenated environment.

Assemblage 2 occurs in both holes in beds immediately underlying (restricted to the unilocular forms and trochamminids) and overlying the CTBE anoxic event. In Hole 603B, a recurrence is also depicted in Cores 603B-26, 603B-25, and 603B$22 \mathrm{R}$. This assemblage is associated with grayish or greenish gray claystones, some of which show slightly increased total organic carbon values (Herbin et al., 1987). 
Such a distribution pattern for the agglutinated benthic foraminifers leads us to assume that a certain correlation does exist between substrate, oxygenation at the seafloor, and composition of the in-situ microfauna. This assumption has to be carefully considered in correlating the stratigraphic ranges of agglutinated taxa in different paleoenvironmental contexts.

The same species may have different biostratigraphic ranges in different paleoenvironments. This appears to be the case particularly for a form considered as an important marker, $U$. jan$k o i$. This species shows a consistent last occurrence in the early/ middle Campanian in the Central North Atlantic (see the preceding) as well as in the Tethyan flysch deposits of the AlpineCarpathian orogenic belt (Moroccan Rif--Morgiel et al., 1980; Kuhnt, 1987; Polish Carpathians-Morgiel and Olszewska, 1981; Geroch and Nowak, 1984; Rumanian CarpathiansNeagu, 1968; Sandulescu; 1973; Czechoslovakian Carpathians-Salaj, 1961; Hanzlikova, 1973). However, at higher latitudes and lesser paleobathymetry, the same form is cited in the upper Maestrichtian (Labrador Shelf-Miller et al., 1982). A study of material from the Labrador Shelf reveals no morphologic differences with the typical $U$. jankoi that occurs in the Tethyan flysch basins.

The same problem arises for the $P$. globigerinaeformis complex, which appears to be stratigraphically limited to a relatively short interval in the DSDP/ODP material and has thus been used by us to define the $P$. globigerinaeformis total range Zone. Apparently identical (or at least highly similar) forms, which do not allow distinction at a specific level, are said to occur up to the Paleocene in the Gubbio sequence and in the Central North Sea (Gradstein et al., in press).

As a result, when using biostratigraphic ranges of these forms for correlation, it seems to be worthwhile to compare for a constant environment, that is, in the same oceanic basin at comparable paleolatitudes, in similar paleobathymetric position, and in a sedimentary context involving a low detrital input.

Moreover, during the Late Cretaceous/Paleocene, the evolution of oceanic biota was characterized by three major and global paleoceanographic events with worldwide repercussions: the Cenomanian/Turonian boundary event, an early/middle Campanian event, and the Cretaceous/Tertiary boundary.

The influence of these events has previously been clearly shown in the evolution of some components of the marine paleoplankton (e.g., planktonic foraminifers and radiolarians; Wonders, 1979; Caron, 1985; Kuhnt et al., 1986). Both the Cenomanian/Turonian boundary and early/middle Campanian events are characterized in deep-sea environments by radiolarian blooms, with a peculiar taxonomic composition for the radiolarian assemblages (see the preceding text). Only the CTBE shows distinct and marked anoxic facies in the deep-sea environment (Thurow et al., this volume).

As shown by this study, the agglutinated deep-sea foraminiferal assemblages seem to have been also affected by these events; there is an abrupt change in the composition of assemblages (from the second to the first assemblage) just above the CTBE, and the early/middle Campanian and the Cretaceous/Tertiary (Hole 640A) events also coincide with significant faunal breaks. Such important faunal changes in the agglutinated assemblages, coeval with worldwide paleoceanographic events, could be regarded as supraregional and time constant, that is, as reliable datum horizons for the biochronology of deep-sea sediments deposited below the carbonate compensation depth.

\section{CONCLUSIONS}

A detailed examination of the distribution of agglutinated benthic foraminifers found in the Upper Cretaceous red clays on both sides of the North Atlantic and an attempt to calibrate the stratigraphic ranges of the consistent marker species have been used to refine the foraminiferal stratigraphy initially proposed for this interval during DSDP Leg 93 (Van Hinte, Wise, et al., 1987) and ODP Leg 103 (Boillot, Winterer, et al., 1987).

Above the highly condensed sequence that spans the Cenomanian/Turonian boundary, sedimentation appears to have been continuous during the Late Cretaceous in both Holes 603B and 641A. However, the foraminiferal zonation reveals an important difference for this period in the history of deposition of the two holes. Although the average sediment-accumulation rate is twice as high in Hole 603B as in Hole 641A, the thickness of beds included in zones 1 and 2 (Turonian-Coniacian) is less in Hole 603B (about $15 \mathrm{~m}$ ) than in Hole 641A (close to $30 \mathrm{~m}$ ). Inversely, zone 3 (mostly Santonian-lower Campanian) is highly abbreviated in Hole 641A (found only in one sample, with a sampling interval of $1.5 \mathrm{~m})$, whereas it is significantly expanded $(38 \mathrm{~m}$ thick) in Hole 603B.

The Upper Cretaceous brown clays across a discontinuity in Aptian-Albian beds in Hole 640A contain agglutinated foraminifers of zone 4, of late Campanian-early/middle Maestrichtian age. Thus, the unconformity in this hole extends from the Cenomanian to the lower Campanian. As far as the Cretaceous/ Tertiary boundary is concerned, a good agreement appears between the ichthyolith stratigraphy, which places the boundary between 84 and $103 \mathrm{~cm}$ in Section 103-640A-2R-1 and the foraminiferal stratigraphy, the results of which place this boundary above Sample 103-640A-2R-1, 109-114 cm, which contains $H$. gigantea, the marker of zone 4 .

This study has shown that agglutinated benthic foraminifers are relatively good stratigraphic indicators in the Upper Cretaceous deep oceanic environment. However, it appears that progress remains to be made in terms of calibration of the zonal schemes and that paleoenvironmental constraints might explain some puzzling discrepancies. As a result, these limitations must be taken carefully into account even in trying to compare and to chronostratigraphically calibrate the biostratigraphic ranges of the best marker species.

\section{ACKNOWLEDGMENTS}

Michel Moullade and Jürgen Thurow wish to thank the Ocean Drilling Program for inviting them to participate on Leg 103 aboard the JOIDES Resolution. Thanks are also extended to James Ogg and Patricia S. Doyle, who kindly communicated results and information, to M. A. Kaminski, for sending material from the Labrador Sea, to J. Tröster for critical comments on the taxonomical part, and to $\mathrm{H}$. Hüttemann for help with the SEM. F. Gradstein, C. Hemleben, C. Schroder and A. W. Meyer reviewed the manuscript. This work was supported by French C.N.R.S. Grant "ATP Géologie-Géophysique des Océans" no. 1243 and by Deutsche Forschung Gemeinschaft Grant Wi 112-25.

\section{REFERENCES}

Arthur, M. A., Schlanger, S. O., and Jenkyns, H. C., 1986. The Cenomanian-Turonian oceanic anoxic event, II. Paleoceanographic controls on organic matter production and preservation. In Brooks, J., and Fleet, A. (Eds.), Marine Petroleum Source Rocks: Spec. Publ. Geol. Soc. London, 26.

Boillot, G., Winterer, E. L., et al., 1987. Proc. ODP, Init. Repts., 103: College Station, TX (Ocean Drilling Program).

Butt, A., 1981. Depositional environments of the Upper Cretaceous rocks in the northern part of the Eastern Alps. Spec. Publ. Cushman Found. Foraminiferal Res., 20:1-121.

Caron, M., 1985. Cretaceous planktic foraminifera. In Bolli, H. M. Saunders, E., and Perch-Nielsen, K. (Eds.), Plankton Stratigraphy: Cambridge (Cambridge Univ. Press), 17-86.

Dumitrica, P., 1970. Cryptocephalic and cryptothoracic Nassellaria in some Mesozoic deposits of Romania. Rev. Roum. Geol. Geophys. Geogr. Ser. Geol., 14:1-124. 
Empson-Morin, K. M., 1981. Campanian radiolaria from DSDP Site 313, Mid-Pacific Mountains. Micropaleontology, 27:249-292. 1984. Depth and latitude distribution of radiolaria in Campanian (Late Cretaceous) tropical and subtropical oceans. Micropaleontology, 30:87-115.

Foreman, H. P., 1971. Cretaceous radiolaria, Leg 7, DSDP. In Winterer, E. L., Riedel, W. R., et al., Init. Repts. DSDP, 7: Washington (U.S. Govt. Printing Office), 1673-1693.

1973. Radiolaria from DSDP Leg 20. In Heezen, B. C., MacGregor, I. D., et al., Init. Repts. DSDP, 20: Washington (U.S. Govt. Printing Office), 249-305.

1978. Mesozoic radiolaria in the Atlantic Ocean off the northwest coast of Africa, Deep Sea Drilling Project, Leg 41. In Lancelot, Y., Seibold, E., et al., Init. Repts. DSDP, 41: Washington (U.S. Govt. Printing Office), 739-761.

Geroch, S., and Nowak, W., 1984. Proposal of zonation for the late Tithonian-late Eocene, based upon arenaceous foraminifera from the Outer Carpathians, Poland. Benthos '83: 2nd Int. Symp Benth. Foraminifera, Pau, 1983, 225-239.

Gradstein, F. M., and Berggren, W. A., 1981. Flysch-type agglutinated foraminifera and the Maestrichtian to Paleogene history of the Labrador and North seas. Mar. Micropaleont., 6:211-268.

Gradstein, F. M., Kaminski, M. A., and Berggren, W. A., in press. Cenozoic foraminiferal biostratigraphy, Central North Sea. Proc. IId Int. Workshop Arenaceous Foraminifera, Vienna (Austria), 1986.

Habib, D., and Drugg, W. S., 1987. Palynology of Sites 603 and 605, Leg 93, Deep Sea Drilling Project. In van Hinte, J. E., Wise, S. W., Jr., et al., Init. Repts. DSDP, 93: Washington (U.S. Govt. Printing Office), 751-775.

Haig, D. W., 1979. Global distribution patterns for mid-Cretaceous foraminiferids. J. Foraminiferal Res., 9:29-40.

Hanzlikova, E., 1973. Foraminifers of the variegated Godula member in Moravia (Cenomanian-Turonian). Sb. Geol. Ved. Paleontol., 15.

Hemleben, C., and Troester, J., 1984. Campanian-Maestrichtian deepwater foraminifers from Hole 543A, Deep Sea Drilling Project. In Biju-Duval, B., Moore J. C., et al., Init. Repts. DSDP, 78A: Washington (U.S. Govt. Printing Office), 509-532.

Herbin, J. P., Montadert, L., Müller, C., Gomez, R., Thurow, J., and Wiedmann, J., 1986. Organic-rich sedimentation at the Cenomanian-Turonian Boundary in oceanic and coastal basins in the North Atlantic and Tethys. In Summerhayes, C. P., and Shackleton, N. J. (Eds.), North Atlantic Palaeoceanography: Spec. Publ. Geol. Soc. London, 22:389-422.

Herbin, J. P., Masure, E., and Roucaché, J., 1987. Cretaceous formations from the lower continental rise off Cape Hatteras: organic geochemistry, dinoflagellate cysts, and the Cenomanian/Turonian boundary event at Sites 603 (Leg 93) and 105 (Leg 11). In van Hinte, J. E., Wise, S. W. Jr., et al., Init. Repts. DSDP, 93: Washington (U.S. Govt. Printing Office), 1139-1162.

Herm, D., 1962. Stratigraphische und mikropaläontologische Untersuchungen der Oberkreide im Lattengebirge und Nierental (Gosaubecken von Reichenhall und Salzburg). Abh. Bayer. Akad. Wiss., Math. Naturwiss. Kl., 104:1-119.

Iwata, K., and Tajika, J., 1986. Late Cretaceous radiolarians of the Yubetsu Group, Tokoro Belt, northeast Hokkaido. J. Fac. Sci. Hokkaido Univ. Ser. 4, 21:619-644.

Kling, S. A., 1982. Radiolarians from the Mariana Trough and Trench region: Deep Sea Drilling Project Leg 60. In Hussong, D. M., Uyeda, S., et al., Init. Repts. DSDP, 60: Washington (U.S. Govt. Printing Office), 537-555.

Krasheninnikov, V. A., 1973. Cretaceous benthonic foraminifera, Leg 20 DSDP. In Heezen, B. C., MacGregor, I. D., et al., Init. Repts. DSDP, 20: Washington (U.S. Govt. Printing Office), 205-219.

1974. Upper Cretaceous benthonic agglutinated foraminifera, Leg 27 DSDP. In Veevers, J. J., Heirtzler, J. R., et al., Init. Repts. DSDP, 27: Washington (U.S. Govt. Printing Office), 631661 .

Krasheninnikov, V. A., and Pflaumann, U., 1977. Cretaceous agglutinated foraminifera of the Atlantic Ocean off West Africa (Leg 41, Deep Sea Drilling Project). In Lancelot, Y., Seibold, E., et al., Init. Repts. DSDP, 41: Washington (U.S. Govt. Printing Office), 565580.
Kuhnt, W., 1987. Biostratigraphie und paläoenvironment der externen Kreideserien des westlichen Rif und Betikum - ein ansatz zur rekonstruktion der kreide-paläogeographie des Gibraltarbogens [Thesis]. Univ. Tübingen.

Kuhnt, W., Thurow, J., Wiedmann, J., and Herbin, J. P., 1986. Oceanic anoxic conditions around the Cenomanian/Turonian Boundary and the response of the biota. In Degens, E. T., Meyers, P. A., and Brassell, S. C. (Eds.), Biogeochemistry of Black Shales, Mitt. Geol. Palaeontol. Inst. Univ. Hamburg, 60:205-246.

McNulty, C. L., 1979. Smaller Cretaceous foraminifers of Leg 43, Deep Sea Drilling Project. In Tucholke, B. E., Vogt P. R., et al., Init. Repts. DSDP, 43: Washington (U.S. Govt. Printing Office), 487505.

1984. Cretaceous foraminifers of Hole 530A, Leg 75, Deep Sea Drilling Project. In Hay, W. W., Sibuet, J.-C., et al., Init. Repts. $D S D P, 75$ : Washington (U.S. Govt. Printing Office), 547-564.

Miller, K. G., Gradstein, F. M., and Berggren, W. A., 1982. Late Cretaceous to early Tertiary agglutinated benthic foraminifera in the Labrador Sea. Micropaleontology, 28:1-30.

Moore, T. C., Jr., 1973. Radiolaria from Leg 17 of the Deep Sea Drilling Project. In Winterer, E. L., Ewing, J. I., et al., Init. Repts. DSDP, 17: Washington (U.S. Govt. Printing Office), 797-869.

Morgiel, J., and Olszewska, B., 1981. Biostratigraphy of the Polish External Carpathians based on agglutinated foraminifera. Micropaleontology, 27:1-10.

Morgiel, J., Olszewska, B., Sikora, W. J., and Wdowiarz, S., 1980. Associations de foraminifères arénacés dans le profil des flyschs du Rif (note préliminaire). Mines, Geol. Energ., 48:25-28.

Nakaseko, K., and Nishimura, A., 1981. Upper Jurassic and Cretaceous radiolaria from the Shimanto Group in southwest Japan. Sci. Rep. Coll. Gen. Educ. Osaka Univ., 30:133-203.

Neagu, T., 1968. Biostratigraphy of Upper Cretaceous deposits in the southern eastern Carpathians near Brasov. Micropaleontology, 14: 225-241

Pessagno, E. A., 1963. Upper Cretaceous radiolaria from Puerto Rico. Micropaleontology, 9:197-214.

1976. Radiolarian zonation and stratigraphy of the Upper Cretaceous portion of the Great Valley Sequence, California Coast Ranges. Micropaleontology Spec. Publ., 2:1-95.

Riedel, W. R., and Sanfilippo, A., 1974. Radiolaria from the southern Indian Ocean, DSDP Leg 26. In Davies, T. A., Luyendyk, B. P., et al., Init. Repts. DSDP, 26: Washington (U.S. Govt. Printing Office), 771-813.

Rögl, F., 1976. Late Cretaceous to Pleistocene foraminifera from the southeast Pacific Basin, DSDP, Leg 35. In Hollister, C. D., Craddock, C., et al., Init. Repts. DSDP, 35: Washington (U.S. Govt. Printing Office), 539-555.

Salaj, J., 1961. Nové stratigrafické poznatky z kriedy vnùtorného bradlového pasma Zapadnych Karpat. Geol. Pr., 22:83-97.

Sandulescu, J., 1973. Etude micropaléontologique et stratigraphique du flysch du Crétacé supérieur-Paleocène de la region de Bretcu, Comandau (secteur interne méridional de la nappe de Tarcau, Carpathes orientales). Mem. Inst. Geol. Rom., 17:1-52.

Sanfilippo, A., and Riedel, W. R., 1985. Cretaceous radiolaria. In Bolli, H. M., Saunders, E., and Perch-Nielsen, K. (Eds.), Plankton Stratigraphy: Cambridge (Cambridge Univ. Press), 573-630.

Schlanger, S. O., 1986. High frequency sea-level fluctuations in Cretaceous time: an emerging geophysical problem. In Hsü, K. J. (Ed.), Mesozoic and Cenozoic Oceans: Washington (Am. Geophys. Union), 61-74.

Sibuet, J.-C., Ryan, W.B.F., et al., 1979. Init. Repts. DSDP, 47, Pt. 2: Washington (U.S. Govt. Printing Office).

Sigal, J., 1979. Chronostratigraphy and ecostratigraphy of Cretaceous formations recovered on DSDP Leg 47B, Site 398. In Sibuet, J.-C., Ryan, W.B.F., et al., Init. Repts. DSDP, 47, Pt. 2: Washington (U.S. Govt. Printing Office), 287-326.

Squinabol, S., 1903. Le radiolarie dei noduli selciosi nella Scaglia degli Euganei: Contribuzione I. Rev. Ital. Paleontol., 9:105-150.

Taketani, Y., 1982. Cretaceous radiolarian biostratigraphy of the Urakawa and Obira areas, Hokkaido. Sci. Rep. Tohoku Univ., Ser. 2, 176.

Thurow, J., 1987. Die kretazischen Turbiditserien im Gibraltarbogen: Bindeglied zwischen atlantischer und tethyaler Entwicklung [Thesis]. Univ. Tübingen. 
Thurow, J., and Kuhnt, W., 1986. Mid-Cretaceous of the Gibraltar Arch Area. In Summerhayes, C. P., and Shackleton, N. J. (Eds.), North Atlantic Palaeoceanography: Spec. Publ. Geol. Soc. London, 22: 423-445.

Thurow, J., Kuhnt, W., and Wiedmann, J., 1982. Zeitlicher und paläogeographischer Rahmen der phtanit- und black shale-sedimentation in Marokko. Neues Jahrb. Geol. Palaeontol. Abh., 165:147176.

van Hinte, J. E., Wise, S. W., Jr,. et al., 1987. Init. Repts. DSDP, 93: Washington (U.S. Govt. Printing Office).

Veevers, J. J., Heirtzler, J. R., et al., 1974. Init. Repts. DSDP, 27: Washington (U.S. Govt. Printing Office).

Wonders, A.A.H., 1979. Middle and Late Cretaceous pelagic sediments of the Umbrian sequence in the central Apennines. Proc. Ned. Akad. Wet., 82:171-205.

Date of initial receipt: 19 February 1987

Date of acceptance: 21 December 1987

Ms 103B-146

\section{APPENDIX \\ Taxonomic Notes \\ Ammodiscus cretaceus (Reuss) \\ (Pl. 1, Fig. 7)}

Operculina cretacea Reuss, 1845, p. 35, pl. 13, figs. 64 and 65.

Ammodiscus cretaceus (Reuss) Krasheninnikov, 1974, p. 643, pl. 7,

fig. 8; Sliter, 1977a, pl. 1, fig. 3; Hemleben and Tröster, p. 517, pl. 1,

fig. 17; Krasheninnikov and Pflaumann, 1977, p. 569, pl. 2, fig. 7.

Remarks. Test composed of relatively broad whorls showing a regular planispiral coiling. Each whorl moderately overlaps the previous one. Surface smooth, wall siliceous, homogeneous or including very fine grains. Proloculus generally visible. Dimensions: 200-520 $\mu \mathrm{m}$.

\section{Dendrophrya excelsa Grzybowski}

Dendrophrya excelsa Grzybowski, 1989, p. 272, pl. 10, figs. 1-4; Krasheninnikov and Pflaumann, 1977, p. 567, pl. 1, figs. 6 and 7.

Remarks. Branched tubes, lacking a distinct central chamber. In the material of Hole $641 \mathrm{~A}$, branched specimens occur very rarely; nevertheless, most of the medium to coarsely agglutinated brown tubes seem to be fragments of this species.

\section{Glomospira charoides (Jones and Parker)}

$$
\text { (Pl. 1, Fig. 6) }
$$

Trochammina squamata Jones and Parker var. charoides Jones and Parker, 1860, p. 304.

Remarks. Long-ranging species, occurring in nearly all samples.

Glomospira corona Cushman and Jarvis

Glomospira charoides (Jones and Parker) var. corona Cushman and Jarvis, 1928, p. 89, pl. 12, figs. 9-11.

Remarks. This long ranging taxon could be just a further growth stage of G. charoides (cf. Hemleben and Tröster, 1984).

\section{Glomospira gordialis (Jones and Parker)}

$$
\text { (Pl. 1, Fig. 4) }
$$

Trochammina squamata Jones and Parker var. gordialis Jones and Parker, 1860 , p. 304.

Remarks. Irregularly coiled tube, the last whorl of which generally lies in one plane; diameter of the tube is small; smooth, very finely agglutinated wall. Long-ranging species, occurring in nearly all samples.

\section{Glomospira(?) irregularis (Grzybowksi)}

Ammodiscus irregularis Grzybowski, 1898, p. 285, pl. 11, figs. 2 and 3. Glomospira? (Tolypammina) irregularis (Grzybowski) Hemleben and Tröster, 1984, p. 519, pl. 1, fig. 22.

Remarks. Differs from all other species of the genus by showing a coarser agglutinated material. Long-ranging species.
Glomospira serpens (Grzybowski)

(Pl. 1, Figs. 2 and 3)

Ammodiscus serpens Grzybowski, 1898, p. 285, pl. 10, figs. 31-33. Glomospira serpens (Grzybowski) Hemleben and Tröster, 1984, p. 519, pl. 1, fig. 23.

Glomospirella gaultina (Berthelin) Krasheninnikov, 1974, p. 643, pl. 7 , figs. 6 and 7; Hanzlikova, 1973, pl. 2, figs. 14 and 15 (non figs. 13 and 16).

Remarks. This species was partly described as Glomospirella gaultina, which shows a similar mode of coiling but a circular and not elongated ellipsoid outline.

\section{Glomospirella gaultina (Berthelin)}

(P1. 1, Fig. 5)

Ammodiscus gaultinus Berthelin, 1880, p. 19, pl. 1, figs. 3a and $3 \mathrm{~b}$.

Glomospira gordialis (Jones and Parker) var. diffundens Cushman and Renz, 1946, p. 15, pl. 1, fig. 30 .

Glomospira grzybowskii Jurkiewicz, 1960, p. 342, pl. 38, figs. 7, 10, and 11.

Glomospirella gaultina (Berthelin) Krasheninnikov and Pflaumann, 1977, p. 568 , pl. 2 , fig. 5 .

Remarks. Our material did not allow us to identify an evolutionary lineage (based on a trend to become planispiral) from Glomospira gordialis to Glomospirella grzybowskii (as mentioned by Hemleben and Tröster, 1984). The various stages (of one to several planispiral coils) are here lumped in a single species.

\section{Haplophragmium lueckei (Cushman and Hedberg)} (Pl. 3, Figs. 1-6)

Ammobaculites lueckei Cushman and Hedberg, 1941, p. 84, pl. 21, figs. 4a and 4b; Neagu, 1970, p. 40, pl. 40, figs. 6-11.

Haplophragmium lueckei (Cushman and Hedberg) Krasheninnikov, 1974, p. 639 , pl. 4 , figs. $3 \mathrm{a}, 3 \mathrm{~b}, 4 \mathrm{a}$, and $5 \mathrm{a}$.

Remarks. The best preserved specimens show an initial nearly planispiral coiling, followed by an uncoiled part that consists of three subcylindrical chambers. Largest dimension (length): $380 \mu \mathrm{m}$.

Our specimens differ from the original description by their apertural characteristics: whereas the holotype has an elliptical opening at the end of a short neck, our material (see Pl. 3, Fig. 6) shows a rounded aperture with a smooth collar rather than an apertural neck. Krasheninnikov (1974), who first attributed deep-sea specimens of the genus Haplophragmium to this species, did not mention their apertural shape.

The flysch form Ammobaculites problematicus Neagu, 1962 shows similar shape and stratigraphic range (mostly Cenomanian to Turonian, rarely lower Senonian, according to Morgiel and Olszewska, 1981); Huss (1966, p. 68-69) also described Haplophragmium aequicameratum from the "argiles marneuses rouges et vertes de Weglowka" (Polish Carpathians) with a stratigraphic range from the Cenomanian to the Coniacian. A taxonomic clarification involving these two forms is needed.

\section{Haplophragmoides bulloides (Beissel)}

(Pl. 6, Figs. 3, 7, and 8)

Haplophragmium bulloides Beissel, 1891, p. 17, pl. 2, figs. 1-3, pl. 4, figs. 24-30.

Halophragmoides bulloides (Beissel) Krasheninnikov, 1974, p. 636, pl. 1, figs. $9 \mathrm{a}, 9 \mathrm{~b}, 10$, and $11 \mathrm{~b}$.

Haplophragmoides suborbicularis (Grzybowski) Webb, 1975, p. 834, pl. 2 , figs. 8 and 9.

Remarks. According to Krasheninnikov (1974), the assimilation between small-sized deep-sea forms showing a morphology similar to $H$. bulloides and large shallow-water forms of Beissel remains tentative. Similar morphotypes of small deep-sea Halophragmoides have been assigned to $H$. suborbicularis (Grzybowski) by Webb (1975) and to $H$. impensus (Martin) by Hanzlikova (1972).

\section{Haplophragmoides(?) sp. cf. bulloides (Beissel)}

$$
\text { (Pl. 6, Figs. 4-6 and 9) }
$$

Remarks. Differs from $H$. bulloides by showing a small, restricted aperture at the base of the final chamber and a generally coarser agglu- 
tinated wall. H. suborbicularis (Grzybowski) from the Paleocene of Poland shows the same apertural feature. Gradstein and Berggren (1981) ascribed similar specimens from the Maestrichtian to Eocene of the Labrador Shelf and North Sea as Cribrostomoides subglobosus (Sars, 1872) and included $H$. suborbicularis in the synonymic list of this form.

\section{Haplophragmoides sp. cf. concavus (Chapman)}

(Pl. 8, Figs. 8 and 9)

Trochammina concava Chapman, 1892, p. 327, pl. 6, figs. 14a and 14b. Haplophragmoides cf. concava (Chapman) Geroch, 1960, p. 127, pl 5, fig. 2.

Remarks. Planispiral, completely flattened and finely agglutinated tests with three to (typically) five chambers in the last whorl. Comparable with $H$. walteri by its narrow compressed rim, but with fewer chambers in the last whorl and a lobate outline.

\section{Haplophragmoides constrictus Krasheninnikov}

$$
\text { (Pl. 4, Figs. 7-9) }
$$

Haplophragmoides constrictus Krasheninnikov, 1973, p. 207-208, pl. 1, figs. 5a and 5b; Krasheninnikov, 1974, p. 635, pl. 1, figs. 3a and 3b.

Remarks. The last whorl consists of six to seven trapezoidal chambers. This form differs from $H$. perexplicatus by a slow increase of the chamber height in the process of growth, a broader umbilicus, and by lacking an elongated final chamber protruding beyond the general contour of the test.

\section{Halophragmoides fraudulentus Krasheninnikov} (Pl. 5, Figs. 7 and 8)

Haplophragmoides fraudulentus Krasheninnikov, 1973, p. 207, pl. 1, figs. 9a and 9b; Krasheninnikov, 1974, p. 634, pl. 1, figs. 1a, 1b, and 2a; Haplophragmoides fraudulentus Krasheninnikov, Hemleben and Tröster, 1984, p. 519, pl. 2, figs. 19 and 20.

Remarks. Test small and evolute, with a broad and shallow umbilicus. Six to seven sphaerical chambers in the last whorl, separated by deep radial to slightly curved sutures.

\section{Haplophragmoides sp. cf. herbichi Neagu} (Pl. 6, Figs. 1 and 2)

Halophragmoides herbichi Neagu, 1968, p. 238, pl. 1, figs. 9-12.

Remarks. Test planispirally coiled, involute, with 9-10 chambers in the last whorl. Peripheral margin rounded. No constrictions visible between the single chambers, thus giving the test a nautiloid appearance. Aperture: a narrow slit at the base of the final chamber. Specimens from Hole 641A differ from Neagu's type form from the Turonian of Romania by having a more distinctly depressed umbilical area. $H$. cf. herbichi differs from $H$. link $i$ Nauss by its greater number of very narrow chambers and by completely lacking sutural constrictions, and from $H$. glabra by lacking slightly depressed sutures.

\section{Haplophragmoides multicamerus Krasheninnikov}

$$
\text { (Pl. 5, Figs. 1 and 2) }
$$

Haplophragmoides multicamerus Krasheninnikov, 1973, p. 207, pl. 1, figs. 6a and 6b; Krasheninnikov, 1974, p. 635, pl. 1, figs. 4a and 4b.

Remarks. Test small and evolute, with a wide and shallow umbilicus; the last whorl consists of seven or eight narrow chambers. Rare form in the studied material.

\section{Haplophragmoides perexplicatus Krasheninnikov} (Pl. 5, Figs. 4-6)

Haplophragmoides perexplicatus Krasheninnikov, 1973, p. 208, pl. 1, figs. $6 \mathrm{a}$ and $6 \mathrm{~b}$; Krasheninnikov, 1974, p. 635, pl. 1, figs. 5a and 5b.

Remarks. Test slightly evolute, showing only a small part of the previous whorl. Five to six chambers in the last whorl, laterally flattened. Outline slightly lobate. This form differs from the other species of Haplophragmoides observed in the deep-sea material mainly by a sharp increase of the height of the last whorl, with a large protruding final chamber.

$H$. pervagatus Krasheninnikov, 1973 may be included in this species. A continuous lineage between $H$. perexplicatus $-H$. constrictus $-H$. multicamerus seems to exist, becoming more evolute and having more chambers in the last whorl.

\section{Haplophragmoides pseudokirki Krasheninnikov}

$$
\text { (Pl. 7, Fig. 7) }
$$

Haplophragmoides pseudokirki Krasheninnikov, 1974, p. 635-636, pl. 1 , figs. $8 \mathrm{a}$ and $8 \mathrm{~b}$.

Remarks. Test entirely involute with four broad subtriangular chambers in the last whorl. Differs from other species of Haplophragmoides and from Labrospira by its apertural features: "the apertural face is low, arch-shaped. The aperture at its base has the form of a high arch; its position is equatorial and does not extend toward the umbilical area" (Krasheninnikov, 1974).

\section{Haplophragmoides sp. cf. walteri (Grzybowski)}

$$
\text { (Pl. 8, Fig. 7) }
$$

Trochammina walteri Grzybowski, 1899, p. 290, pl. 11, fig. 31.

Haplophragmoides cf. walteri (Grzybowski) Hemleben and Tröster, 1984, p. 519 , pl. 3, fig. 6 .

Remarks. Test typically compressed as in $H$. cf. concavus (Chapman) but differing by a less lobular, nearly circular periphery, a greater number of chambers (six-seven) in the last whorl, and a less distinct separation of chambers.

\section{Hormosina crassa Geroch}

(Pl. 2, Figs. 4-6)

Hormosina ovulum crassa Geroch, 1966, p. 438, figs. 6 (19, and 21-26) and 7 (21-23); Hemleben and Tröster, 1984, p. 520, pl. 2, figs. 8 and 9.

Remarks. Test more coarsely agglutinated than in the other species of the genus Hormosina, with sphaerical chambers linked by thick connections. Intermediate forms to Hyperammina subdiscreta and to Hormosina ovulum seem to exist.

Stratigraphic range. Barremian to Maestrichtian.

\section{Hormosina gigantea Geroch

$$
\text { (Pl. 2, Fig. 11) }
$$

Hormosina ovulum (Grzybowski) var. gigantea Geroch, 1960, p. 43, pl. 2, figs. 18 and 19.

Remarks. Differs from $H$. ovulum (Grzybowksi) by its larger size (in most cases, exceeding $500 \mu \mathrm{m}$; the largest diameter measured in Hole $641 \mathrm{~A}$ material is $670 \mu \mathrm{m}$ ) and more globular outline of the chambers.

Stratigraphic range. More restricted than that of $H$. ovulum: Campanian to lower Maestrichtian in the Gibraltar Arch area and Campanian to lower Paleocene in the Carpathian flysch (according to Geroch, 1960, and Geroch and Nowak, 1984).

\section{Hormosina ovuloides (Grzybowski)}

(Pl. 2, Fig. 10)

Reophax ovuloides Grzybowski, 1901, p. 223, pl. 8, fig. 3.

Hormosina ovuloides (Grzybowski) Hemleben and Tröster, 1984, p. 520, pl. 2, fig. 6 .

Remarks. Test composed of more elongated and asymmetrical chambers than in $H$. ovulum. Connections of chambers are relatively broad.

\section{Hormosina ovulum (Grzybowski)}

$$
\text { (Pl. 2, Figs. 7-9) }
$$

Reophax ovulum Grzybowski, 1896, p. 276, pl. 8, figs. 19-21.

Remarks. Test similar to $H$. gigantea by its smooth surface and narrow connections between chambers, but it has a smaller size (200-400 $\mu \mathrm{m})$. Though intermediate forms appear to exist, the two species have different stratigraphic ranges (Geroch and Nowak, 1984). The extremely elongated specimens show some similarities with $H$. ovuloides, but are distinguished from this species by their narrow connections between chambers and by a more symmetrical egglike shape.

\section{Hyperammina ex gr. elongata Brady}

Hyperammina elongata Brady, 1884, p. 257, pl. 23, figs. 4 and 7-10. Hyperamina ex gr. elongata Brady, Krasheninnikov, 1974, p. 644, pl. 7, figs. 13 and 14; Hemleben and Tröster, 1984, p. 520, pl. 1, figs. 12 and 13.

Remarks. A Hyperammina without constrictions in the linear part of the chamber. 
Hyperammina subdiscreta (Grzybowski)

$$
\text { (Pl. 2, Figs. 1-3) }
$$

Rhabdammina subdiscreta Rzehak, Grzybowski, 1896, p. 275, pl. 8 , figs. 5 and 6.

Hyperammina subdiscreta (Grzybowski) Liszka and Liszkowa, 1981, p. 164, pl. 1 , figs. $2 \mathrm{a}$ and $2 \mathrm{~b}$

Hyperammina cf. dilatata Grzybowski, Hemleben and Tröster, 1984 p. 520 , pl. 1 , figs. 10 and 11 .

Rhabdammina subdiscreta Grzybowski, Hemleben and Tröster, 1984, p. 522, pl. 1, figs. 1 and 2 .

Remarks. Coarsely agglutinated tubes, with constrictions and globular, ovoid widenings. Differs from Hyperammina dilatata by showing broader tubular sections, a smaller proloculus, and generally coarser agglutinated particles. Slightly curved forms show similarities with Hyperammina nodata Grzybowski, 1896.

Hyperammina subdiscreta differs from Hormosina crassa by its more irregularly shaped ovoid widenings, whereas $H$. crassa has globular, separated chambers. In this latter species, tubes between chambers are narrow, short, or broken away.

Forms quite similar to $H$. subdiscreta have been described and illustrated as Hormosina excelsa (Dylazanka, 1923) by Grün (1969), Hanzlikova (1973), Morgiel and Olszewska (1981), and Geroch and Nowak (1984). However, Dylazanka's original description and figuration differ from these forms by showing a smooth, glasslike wall texture, and pearshaped chambers, broadening in the upper part and strongly tapering at the lower end. $H$. excelsa (sensu auctorum) is regarded by Morgiel and Olszewska (1981) and Geroch and Nowak (1984) as a valuable guide form, with a first appearance in the upper Senonian ( $U$. jankoi Zone of Geroch and Nowak, 1984).

Labrospira inflata Krasheninnikov

(Pl. 6, Figs. 9 and 10)

Labrospira inflata Krashenninikov, 1974, p. 637, pl. 2, figs. 6a, 6b, and 7 b; Hemleben and Tröster, 1984, p. 520, pl. 3, fig. 7.

Remarks. Very finely agglutinated test, with an almost sphaerical outline and often a slightly asymmetrical final chamber. Typical aperture of Labrospira, well visible. Transitional forms to $L$. pacifica seem to exist.

\section{Labrospira pacifica Krasheninnikov}

$$
\text { (Pl. 7, Fig. 8) }
$$

Labrospira pacifica Krasheninnikov, 1973, p. 209, pl. 2, figs. 4a, 4b, 5a and 5b; Krasheninnikov, 1974, p. 637, pl. 3, figs. $1 \mathrm{a}, 1 \mathrm{~b}, 2 \mathrm{a}$, and $2 \mathrm{~b}$; Gradstein and Berggren, 1981, p. 260, pl. 9, figs. 9 and 10; Hemleben and Tröster, 1984 , p. 520, pl. 3, fig. 8.

\section{Paratrochamminoides sp. cf. acervulatus (Grzybowski)}

$$
\text { (Pl. 3, Figs. } 7 \text { and 10) }
$$

Trochammina acervulata Grzybowski, 1896, p. 284, pl. 9, figs. 4a-4c; Liszka and Liszkowa, 1981, p. 176, pl. 3, figs. 1a-1c.

Remarks. Though showing the typical arrangement of globular to ovoid chambers, specimens from our material differ from the illustrated Grzybowski's specimen in size $(1.5 \mathrm{~mm}$ according to the original description). However, Liszka and Liszkowa (1981) figured a specimen taken from Grzybowski's collection, closely conforming with author's original description and illustration, which has a diameter of $600 \mu \mathrm{m}$ and a height of $300 \mu \mathrm{m}$.

\section{Paratrochamminoides corpulentus Krasheninnikov}

$$
\text { (P1. 3, Figs. } 8 \text { and 9) }
$$

Paratrochamminoides corpulentus Krasheninnikov, 1973, p. 212, pl. 3, figs. $3 a-3 c$.

Paratrochamminoides conglobatus (Brady) Hemleben and Tröster, 1984, p. 520, pl. 3, fig. 9 .

Paratrochamminoides semipellucidus Krasheninnikov, Hemleben and Tröster, 1984, p. 520, pl. 3, figs. 12-14.

Paratrochamminoides sp. 2, Hemleben and Tröster, 1984, p. 521, pl. 3, fig. 18.

Remarks. Test with an elliptical outline (not sphaerical as in $P$. conglobatus). Chambers elongated, with indistinct sutures. In contrast to $P$ semipellucidus, the umbilical deepenings are absent. The morphology of the test of our specimens is almost identical with that of Krasheninnikov's holotype. Wall smooth, very finely agglutinated; more coarsely agglutinated specimens occur rarely. Dimensions (longer diameter): 310 $\mu \mathrm{m}$.

\section{Paratrochamminoides intricatus Krasheninnikov}

Paratrochamminoides intricatus Krasheninnikov, 1973, p. 212, pl. 3, figs. 2a-2c; Krasheninnikov, 1974, p. 638, pl. 4, figs. 2a-2c; Hemleben and Tröster, 1984, p. 520, pl. 3, figs. 10 and 11

Remarks. Chambers globular, slowly increasing in size as added. Test irregularly coiled, with an irregular trochospire in the early part, the last whorl being perpendicular to the coiling of the trochospire. Relatively low arched aperture at the base of a convex apertural face.

\section{Paratrochamminoides sp.}

Remarks. Large, irregularly chambered tests, generally fragmented. Largest diameter: about $500 \mu \mathrm{m}$.

\section{Plectina conversa (Grzybowski)}

(P1. 9, Figs. 1-3)

Gaudryina conversa Grzybowski, 1901, p. 285, pl. 7, figs. 15 and 16 . Plectina conversa (Grzybowski) Krasheninnikov and Pflaumann, 1977, p. $569, \mathrm{pl} .3$, figs. $4 \mathrm{a}$ and $4 \mathrm{~b}$

Plectina aff. conversa (Grzybowski) Krasheninnikov, 1974, p. 643, pl. 7, figs. $3 \mathrm{a}, 3 \mathrm{~b}$, and $4 \mathrm{a}$.

Remarks. Test elongate with an initial trochospiral and a later biserial, slightly twisted, stage, consisting of four to five pairs of chambers.

\section{Plectina sp. cf. lenis (Grzybowski)}

(Pl. 9, Fig. 4)

Spiroplecta lenis Grzybowski, 1896, p. 288, pl. 9, figs, 24 and 25.

Plectina lenis (Grzybowski) Liszka and Liszkowa, 1981, p. 181, pl. 4, figs. $3 \mathrm{a}, 3 \mathrm{~b}, 4$, and 5 .

Plectina aff. conversa (Grzybowski) Hemleben and Tröster, p. 521, pl. 4 , fig. 24 .

Remarks. Test lacking a biserial part or showing a short, not twisted, biserial stage, consisting of one to three pairs of chambers. In our material, so many intermediate forms exist between $P$. convers $a$ and $P$. sp. cf. lenis that these two species have not been separated in the range charts.

\section{Praecystammina globigerinaeformis Krasheninnikov}

$$
\text { (Pl. 7, Fig. 6) }
$$

Praecystammina globigerinaeformis Krasheninnikov, 1973, p. 211, pl. 3, figs. 1a-1c and 2; Krasheninnikov, 1974, p. 641, pl. 6, figs. 1a-1c and 3a; Gradstein and Berggren, 1981 , p. 258, pl. 9, figs. 11 15 ; Hemleben and Tröster, 1984, p. 521, pl. 4, fig. 8.

Cystammina globigerinaeformis (Krasheninnikov) Miller et al., 1982, p. 21 , pl. 2 , figs. 13,17 , and 21 .

Remarks. Four related genera are defined by their apertural characteristics, together with the shape of their chambers, as follows:

Cystammina Neumayr, 1889: slitlike aperture above the base of the last chamber; test with high, inflated, elongate chambers.

Ammosphaeroidina Cushman, 1910: low archlike aperture at the base of the last chamber; test globose with three embracing chambers in the last whorl.

Cystamminella Mjatliuk, 1966: slitlike aperture at the base of the last chamber; few oval chambers.

Praecystammina Krasheninnikov, 1973: (from the original description) "aperture comprising oval slit in face of the last chamber, above and parallel to basal margin of this chamber (areal), bordered by thin lip or low neck"; the last whorl shows three oval, hemisphaerical chambers. According to Krasheninnikov (1973), Praecystammina and Cystammina have the same apertural features and differ only by the shape of chambers.

In our material, owing to preservation problems, only a few specimens distinctly show the typical apertural features of Praecystammina. We tentatively lumped as Praecystammina all the morphotypes having few oval, hemisphaerical chambers. A further taxonomic revision of 
these forms, including deep-sea and flysch-type material, appears needed. Thus, the different stratigraphic ranges mentioned in the literature for $P$. globigerinaeformis found in deep-sea material and for apparently similar morphotypes in onshore sections could be the result of taxonomic misidentifications.

Praecystammina(?) sp. aff. globigerinaeformis Krasheninnikov (Pl. 7, Figs. 1-4)

?Cystamminella pseudopauciloculata Mjatliuk, 1966, p. 264-265, pl. 1, figs. $5-8$, pl. 2 , fig. 6 , and pl. 3 , fig. 3 .

Remarks. Differs from the typical form by a coarser agglutinated wall and the position of the aperture at the base (and not slightly above the basal margin) of the last chamber. Although these forms are morphologically identical to $P$. globigerinaeformis, their apertural features correspond to the (generally compressed) species Cystamminella pseudopauciloculata Mjatliuk.

Praecystammina(?) sp. cf. globigerinaeformis Krasheninnikov (Pl. 7, Fig. 5)

?Cystamminella pseudopauciloculata Mjatliuk, 1966, p. 264-265, pl. 1, figs. $5-8$, pl. 2 , fig. 6 , and pl. 3 , fig. 3 .

Remarks. Test very finely agglutinated, strongly compressed, with three to four slightly elongated chambers visible on each side. No aperture visible owing to the strong compression. Diameter: 200-250 $\mu \mathrm{m}$. These forms most probably represent flattened (by diagenetic compaction) specimens of $P$ (?) globigerinaeformis.

Pseudobolivina lagenaria Krasheninnikov (Pl. 9, Figs. 7 and 8)

Pseudobolivina lagenaria Krasheninnikov, 1974, p. 639-640, pl. 5, figs. $1 \mathrm{a}, 1 \mathrm{~b}$, and $2 \mathrm{c}$

Remarks. This species is characterized by a trend to an uniserial arrangement of the last chambers and by a distinct apertural neck.

\section{Pseudobolivina munda Krasheninnikov}

(Pl. 9, Figs. 9 and 10)

Pseudobolivina munda Krasheninnikov, 1973, p. 210, pl. 2, figs. 10 and 11; Krasheninnikov, 1974, p. 639, pl. 4, figs. $6 \mathrm{a}, 6 \mathrm{~b}$, and 7a; Hemleben and Tröster, 1984, p. 521, pl. 4, fig. 3.

Remarks. Test narrow, wedge shaped, and elongated. Chambers oval, elongated in the direction of growth, and gradually increasing in size as added.

Pseudobolivina sp. 1

(P1. 9, Figs. 5 and 6)

Remarks. Resembles the early stage of $P$. lagenaria, but the last chamber lacks an apertural neck.

Pseudobolivina(?) sp. 2

(Pl. 9, Figs. 11 and 12)

Remarks. Last chamber strongly compressed, showing a trend to becoming uniserial. Seems to possess an apertural neck.

\section{Recurvoides sp. cf. deflexiformis (Noth)}

$$
\text { (Pl. 4, Figs. } 3 \text { and 4) }
$$

Trochammina deflexiformis Noth, 1912, p. 14, pl. 1, figs. 10a and 10b. Recurvoides ex. gr. deflexiformis (Noth) Krasheninnikov, 1974, p. 639 pl. 3 , figs. $4 a-4 c, 5 a$, and $5 b$.

Remarks. This species shows a change in the coiling direction of about $90^{\circ}$. Sutures of chambers depressed. Typical (areal, oval) Recurvoides aperture.

\section{Recurvoides sp. cf. pseudosymmetricus Krasheninnikov}

$$
\text { (Pl. 4, Fig. 5) }
$$

Recurvoides pseudosymmetricus Krasheninnikov, 1974, p. 638, pl. 3, figs. 3a-3c.

Remarks. Our specimens differ from those of Krasheninnikov in being laterally more compressed. This form differs from the other species of the genus by its pseudosymmetrical coiling. Aperture areal and oval.

\section{Recurvoides sp. 1}

$$
\text { (Pl. 4, Fig. 1) }
$$

Remarks. Coarsely agglutinated form with a typical streptospiral coiling. Because of the coarse agglutination, the single chambers are difficult to distinguish.

Recurvoides sp. 2

(Pl. 4, Fig. 2)

Remarks. Differs from the other species of the genus by its apertural features (an elongated slit in the lower part of the apertural face).

\section{Reophax sp. aff. dentaliniformis Brady}

(Pl. 1, Figs. 8-11)

Reophax dentaliniformis Brady, 1884, pl. 30, figs. 21 and 22.

Hormosina dentaliniformis (Brady) Brönnimann and Whittaker, 1980, p. 265-266, figs. 8 and 9.

Reophax liasica Franke, Noth, 1951, p. 25, pl. 2, fig. 5.

Remarks. Two different types coexist in our material

1. Small, two- or three-chambered specimens with a large sphaerical proloculus and elongated second/third chamber. These forms are morphologically quite similar to those described from the Albian of Austria as Reophax liasica Franke by Noth (1951).

2. Larger, generally five-chambered specimens with a smaller, elongated proluculus. These forms are morphologically comparable with the recent species Reophax dentaliniformis.

However, by the similar shape of chambers, these two types seem to belong to the same specific taxon.

\section{Reophax sp. aff. guttifer Brady}

(Pl. 1, Fig. 12)

Reophax guttifer Brady, 1884, pl. 31, figs. 10-15.

Chambers. Chambers separated by narrow necks. Our Cretaceous specimens are assigned to this recent species by reason of morphological similarities.

\section{Rhabdammina sp. aff. abyssorum Sars}

(Pl. 1, Fig. 1)

Rhabdammina abyssorum Sars, 1869, p. 61; Loeblich and Tappan, 1964, p. 185-186, figs. 103-105.

Remarks. Tiny branched tubes (diameter about $25 \mu \mathrm{m}$, maximal length $100-150 \mu \mathrm{m})$, medium to coarsely agglutinated. The branched fragments show a small, indistinct central chamber.

\section{Saccammina grzybowskii (Schubert)}

Reophax grzybowskii Schubert, 1901, p. 20, pl. 1, figs. 13 and 13b. Saccammina grzybowskii (Schubert) Hemleben and Tröster, 1984, p. 522 , pl. 1, fig. 14

Remarks. Test flat, oval, or circular disc-shaped, commonly showing a central depression. Aperture found anywhere on the test. Dimensions: $200-400 \mu \mathrm{m}$

\section{Saccammina sphaerica Sars \\ (Pl. 2, Fig. 12)}

Saccammina sphaerica Sars, 1872, p. 250; Carpenter, 1875, p. 532, pls. 272a-272c; Hemleben and Tröster, 1984, p. 522, pl. 1, fig. 15.

Saccammina complanata (Franke) Krasheninnikov, 1974, p. 644, pl. 7, figs. 10 and $10 \mathrm{~b}$.

Remarks. Test perfectly sphaerical with a single aperture. Morphologically similar to the primary chambers of Hormosina gigantea, but the wall of $S$. sphaerica is coarsely agglutinated. S. grzybowskii can be a junior synonym of $S$. sphaerica because the compressed outline of the former might be due to sedimentary features (diagenetic compaction).

\section{Trochammina altiformis Cushman and Renz}

$$
\text { (Pl. 8, Figs. 1-3) }
$$

Trochammina globigeriniformis (Parker and Jones) var. altiformis Cushman and Renz, 1946, p. 24, pl. 3, figs. 7-11 
Trochammina globigeriniformis altiformis Cushman and Renz, Krasheninnikov, 1974, p. 641, pl. 6, figs. 4a-4c and 5a.

Trochammina globigeriniformis (Parker and Jones) altiformis Cushman and Renz, Krasheninnikov and Pflaumann, 1977, p. 570, pl. 4, figs. $8 \mathrm{a}-8 \mathrm{c}$.

Remarks. Test coarsely agglutinated, with a nearly plane to slightly convex dorsal side and a highly convex ventral side. Generally reported from Upper Cretaceous sequences, although specimens mentioned by Krasheninnikov and Pflaumann (1977) come from the Aptian/Albian of the Moroccan Basin.

\section{Trochammina bulloidiformis (Grzybowski)}

(Pl. 4, Fig. 6)

Haplophragmium (Reussina) bulloidiforme Grzybowski, 1896, p. 278, pl. 8, figs. $32 \mathrm{a}-32 \mathrm{c}$ and $33 \mathrm{a}-33 \mathrm{c}$.

Haplophragmium (Reussina) quadriloba Grzybowski, 1896, p. 278, pl. 8, figs. 31.

Trochammina quadriloba (Grzybowski) Geroch, 1960, p. 134, pl. 8, fig. 1.

Trochammina bulloidiformis (Grzybowski) Liszka and Liszkowa, 1891, pl. 1, figs. 16a, 16b, 17, 18a, and 18b.

Remarks. Test extremely coarsely agglutinated (quartz grains with a size up to $50 \mu \mathrm{m}$ ). Three chambers in the last whorl, nearly equal in size and arranged in a single plane. The earlier part of the test consists of a single chamber of equal size, lying on the three last chambers.
Trochammina gyroidinaeformis Krasheninnikov

(Pl. 8, Figs. 4-6)

Trochammina gyroidinaeformis Krasheninnikov, 1974, p. 641, pl. 5, figs. 7a-7c and 8a-8c; Hemleben and Tröster, 1984, p. 522, pl. 4, figs. 11-13.

Remarks. Abundant in Hole 603B, scarce in Hole 641A.

\section{Uvigerinammina jankoi Majzon}

(Pl. 10, Figs. 1-6)

Uvigerinammina jankoi Majzon, 1943, p. 158, pl. 2, figs. $15 \mathrm{a}$ and $15 \mathrm{~b}$; Geroch, 1957 , p. $238-244$, pls. 14 and 15; Krasheninnikov, 1974 , p. 642, pl. 6, figs. 9a, 9b, and 10a; Krasheninnikov and Pflaumann, 1977, p. 569, pl. 3, figs. 12 and 13; Hemleben and Tröster, 1984, p. 522, pl. 4, fig. 20.

Remarks. This species is common in flysch-type agglutinated foraminiferal assemblages. In our material, typical specimens with a subcircular section and small elongated chambers without constrictions coexist with more "angular" forms, with three large, distinctly separated, final chambers, giving the test a tricarinate outline. There are also intermediate specimens.

Stratigraphic range. Mentioned from Cenomanian to Maestrichtian, with a distinct acme from Turonian to lower Campanian. 


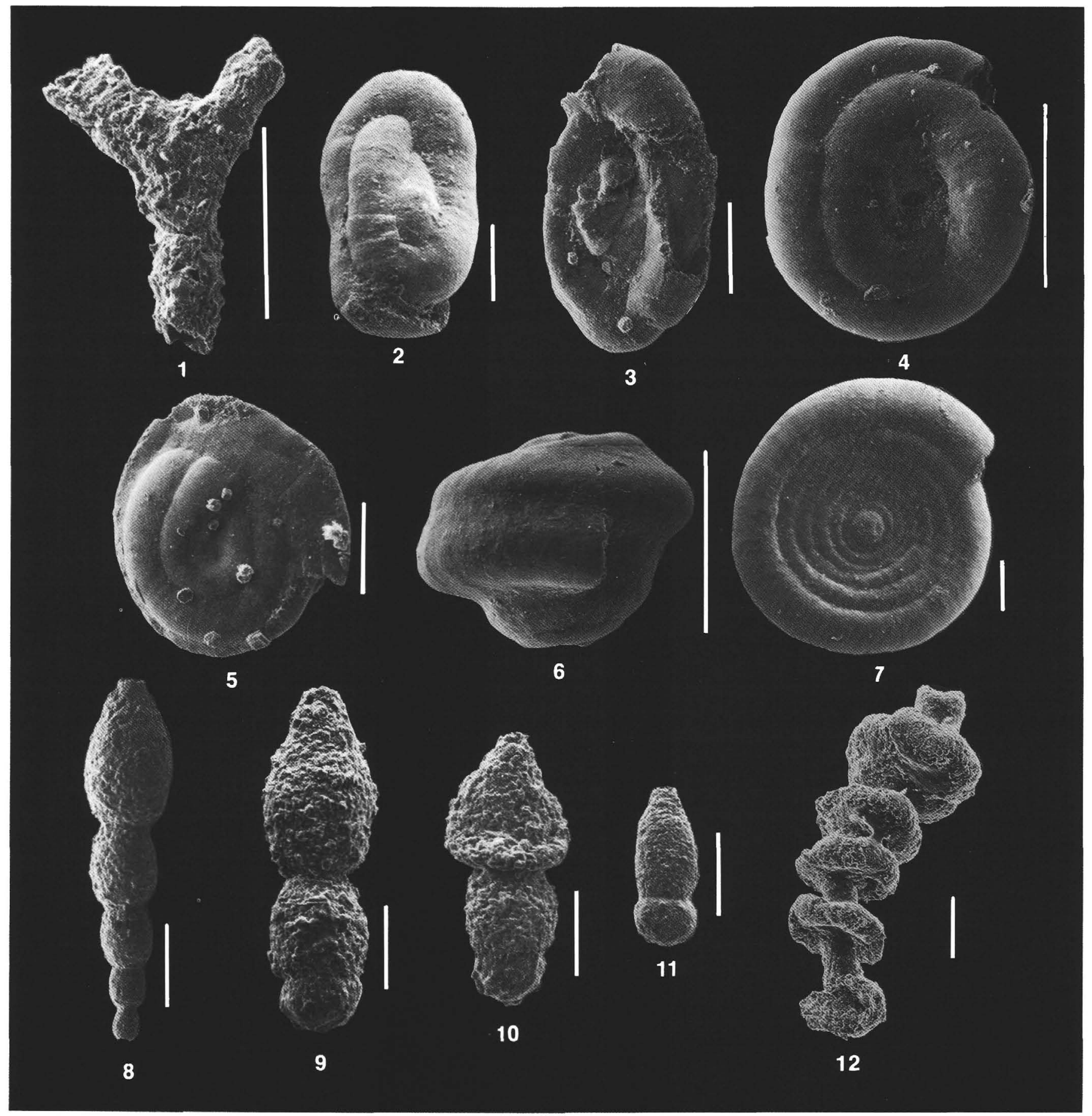

Plate 1. Scale bars equal $100 \mu \mathrm{m}$. 1. Rhabdammina abyssorum Sars, Sample 103-641A-6X-7, 24-26 cm. 2. Glomospira serpens (Grzybowski), Sample 103-641A-2X-2, 0-3 cm. 3. Glomospira serpens (Grzybowski), Section 103-641A-4X, CC. 4. Glomospira gordialis (Jones and Parker), Section 103-641A-4X, CC. 5. Glomospirella gaultina (Berthelin), Section 103-641A-4X, CC. 6. Glomospira charoides (Jones and Parker), Section 103-641A-4X, CC. 7. Ammodiscus cretaceus (Reuss), Sample 103-641A-2X-2, 0-3 cm. 8. Reophax sp. aff. dentaliniformis Brady, Sample 603B30-3, 88-91 cm. 9. Reophax sp. aff. dentaliniformis Brady, Section 603B-31, CC. 10 and 11. Reophax sp. aff. dentaliniformis Brady, Sample 603B-31-4, 54-57 cm. 12. Reophax sp. aff. guttifer Brady, Sample 603B-31-4, 54-57 cm. 


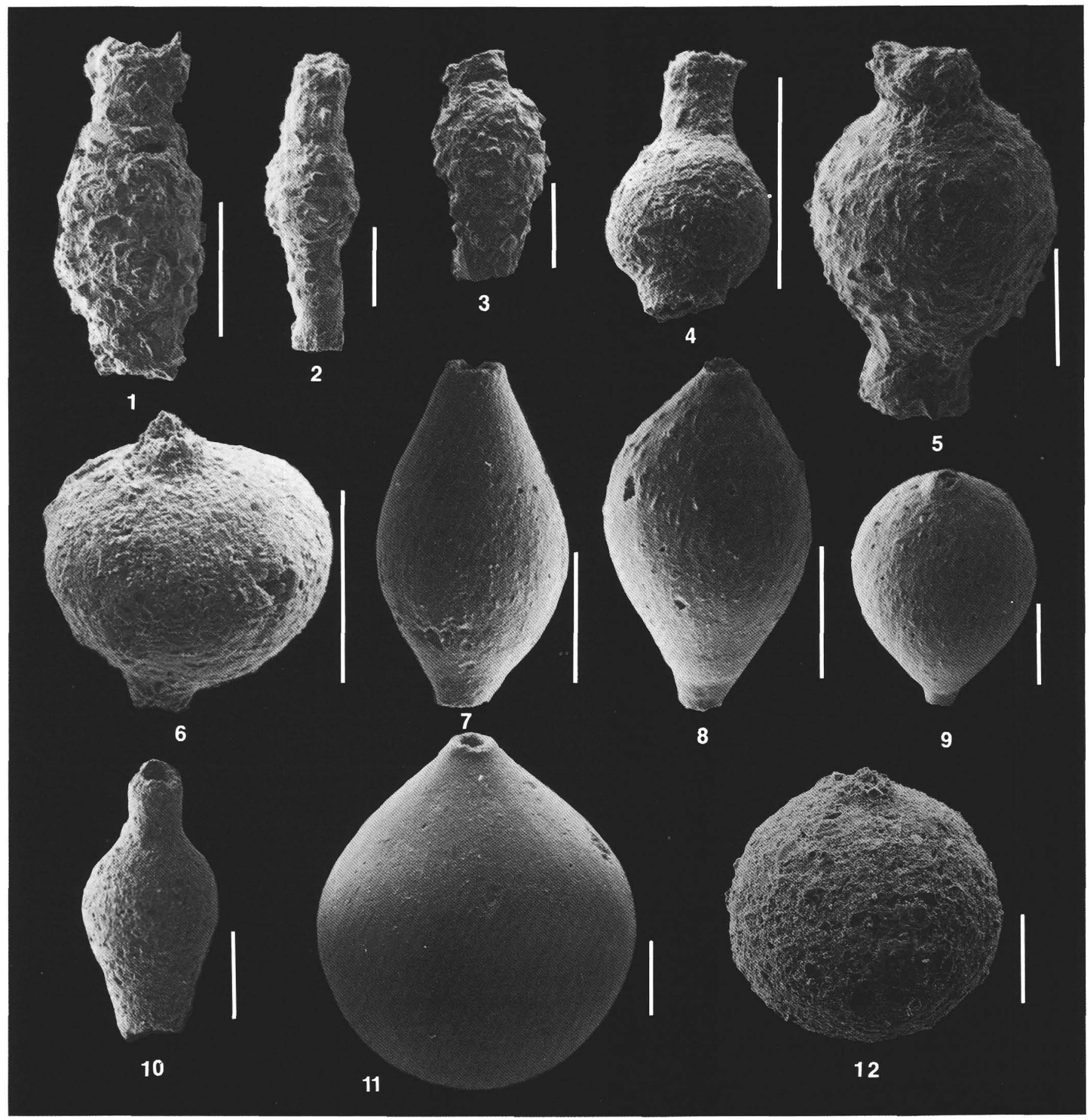

Plate 2. Scale bars equal $100 \mu \mathrm{m}$. 1 and 2. Hyperammina subdiscreta (Grzybowski), Sample 103-641A-1X-2, 109-114 cm. 3. Hyperammina subdiscreta (Grzybowski), Sample 103-641A-1X-4, 12-17 cm. 4. Hormosina crassa Geroch, Section 103-641A-5X, CC. 5. Hormosina crassa Geroch, Section 103-641A-2X, CC. 6. Hormosina crassa Geroch, Sample 103-641 A-1X-2, 109-114 cm. 7. Hormosina ovulum (Grzybowski), Section 103-641A-2X, CC. 8. Hormosina ovulum (Grzybowski), Section 103-641A-1X, CC. 9. Hormosina ovulum (Grzybowski), Section 103-641A2X, CC. 10. Hormosina ovuloides (Grzybowski), Sample 103-641A-1X-4, 12-17 cm. 11. Hormosina gigantea Geroch, Section 103-641A-1X, CC. 12. Saccammina sphaerica Sars, Sample 103-641A-1X-2, 109-114 cm. 


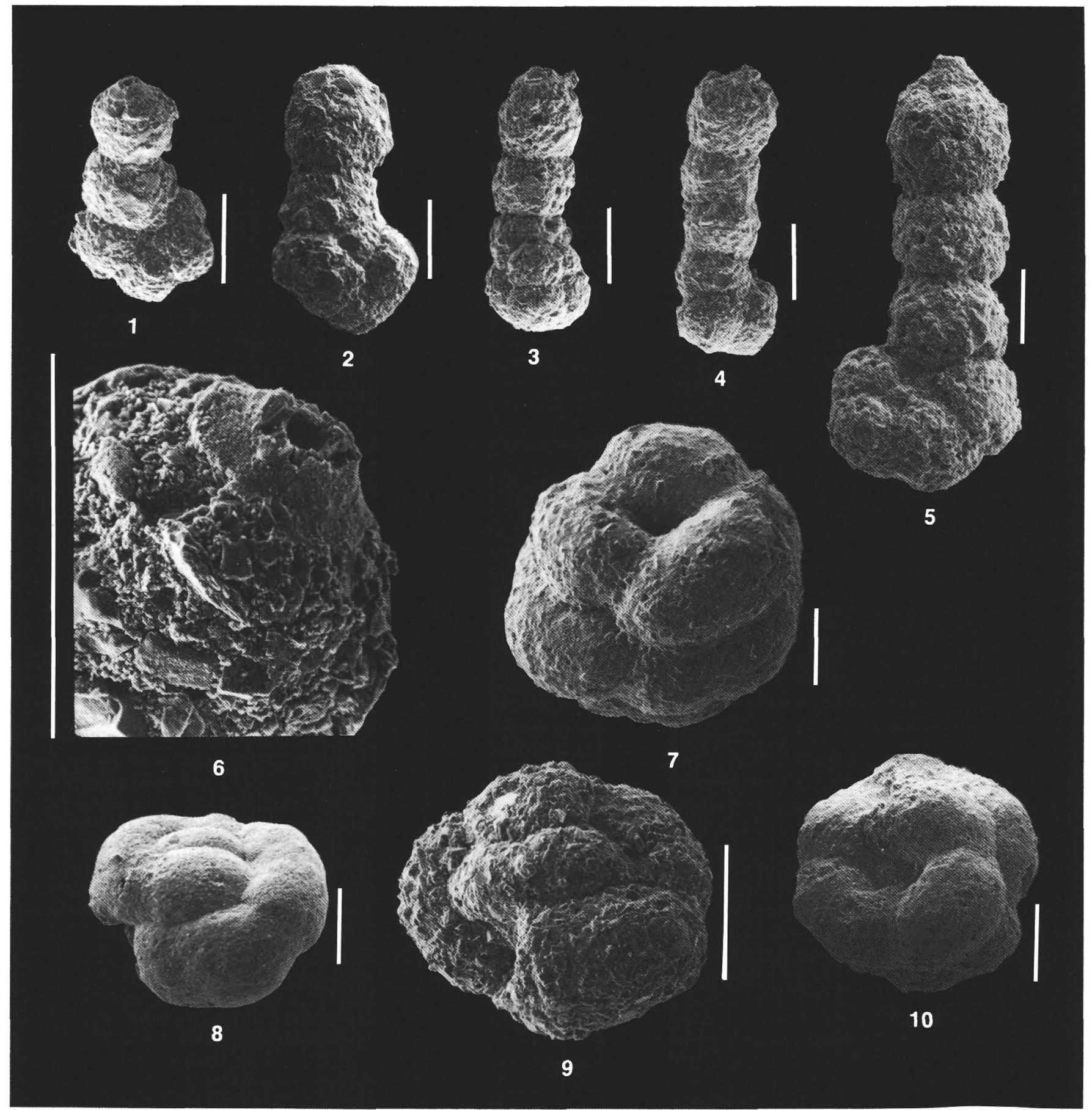

Plate 3. Scale bars equal $100 \mu \mathrm{m}$. 1-5. Haplophragmium lueckei (Cushman and Hedberg), Section 103-641A-5X, CC. 6. Detail of specimen shown in Figure 1. 7. Paratrochamminoides sp. cf. acervulatus (Grzybowski), Section 103-641A-2X, CC. 8 and 9. Paratrochamminoides corpulentus Krasheninnikov, Sample 103-641A-1X-2, 109-114 cm. 10. Paratrochamminoides sp. cf. acervulatus (Grzybowski), Sample 103-641A-1X-2, $109-114 \mathrm{~cm}$. 


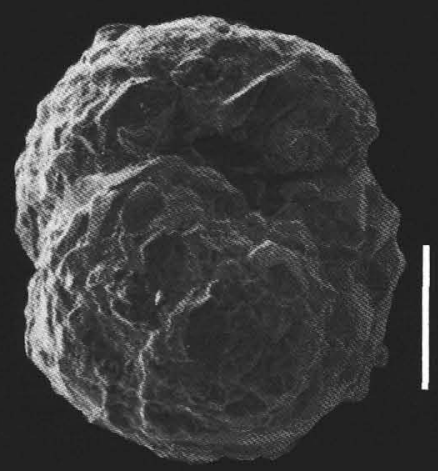

1

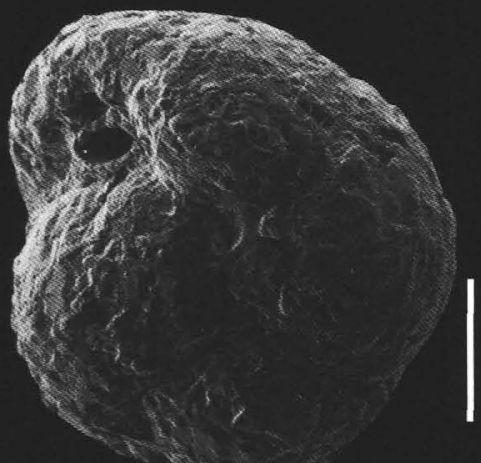

4

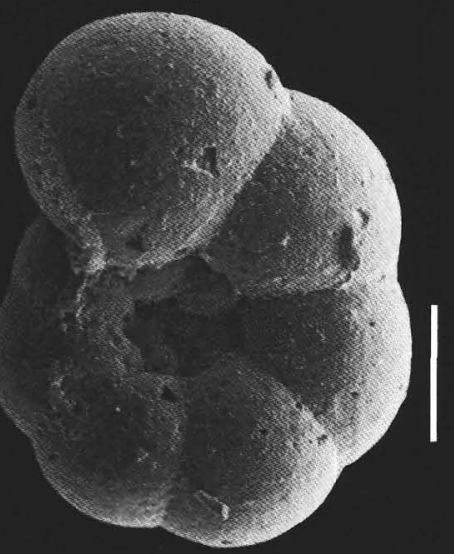

7

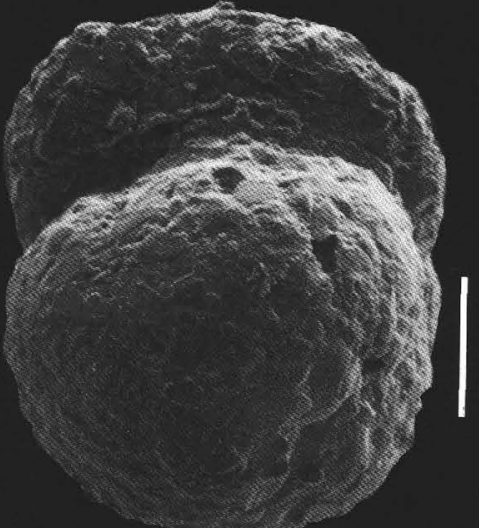

2

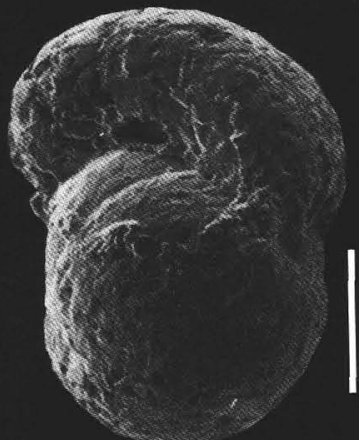

5

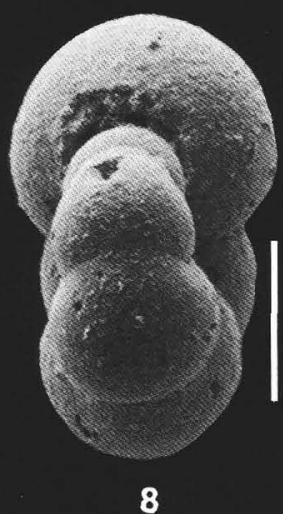

8

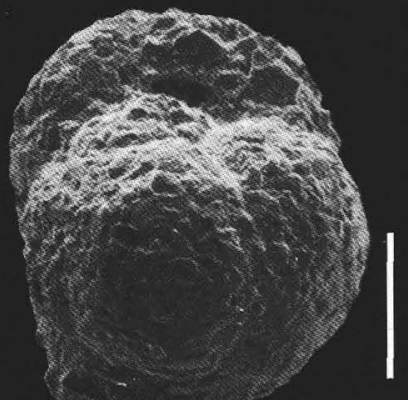

3

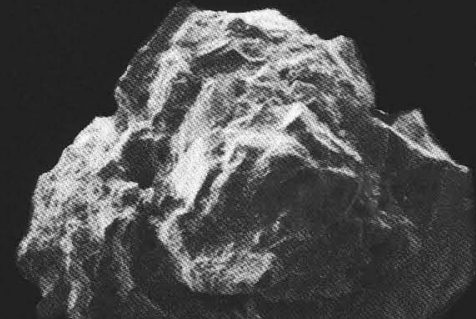

6

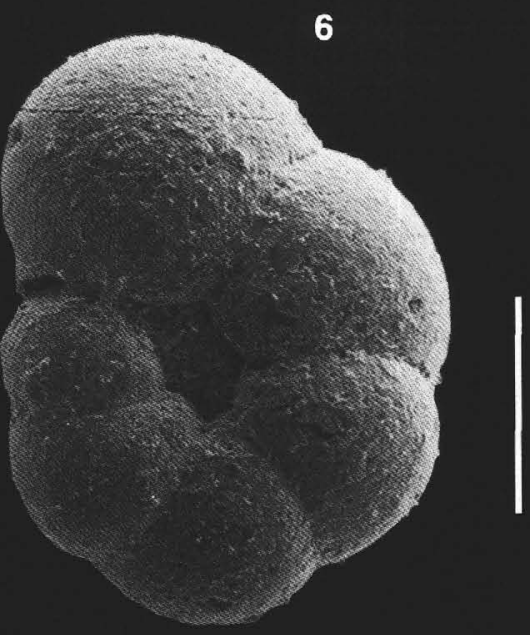

9

Plate 4. Scale bars equal $100 \mu \mathrm{m}$. 1. Recurvoides sp. 1, Sample 603B-33-1, 38-42 cm. 2. Recurvoides sp., 2, Sample 603B-33-1, 38-42 cm. 3. Recurvoides sp. cf. deflexiformis (Noth), Sample 603B-31-1, 60-63 cm. 4. Recurvoides sp. cf. deflexiformis (Noth), Section 603B-31, CC. 5. Recurvoides sp. cf. pseudosymmetricus Krasheninnikov, Section 603B-31R, CC. 6. Trochammina bulloidiformis (Grzybowski), Section 103-641A$1 \mathrm{X}, \mathrm{CC}$. 7-9. Haplophragmoides constrictus Krasheninnikov, Section 103-641A-2X, CC. 


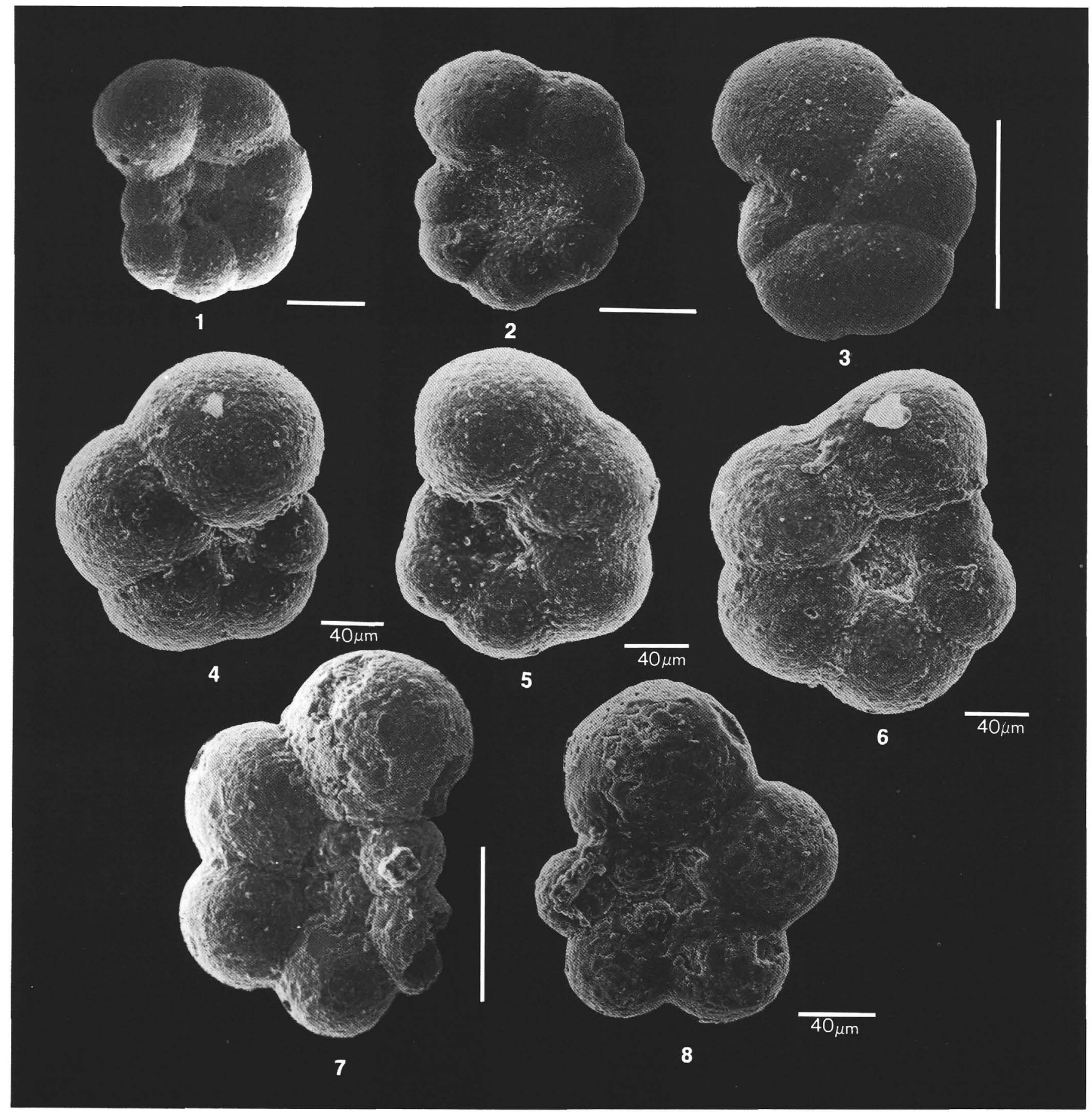

Plate 5. Unless specified, scale bars equal $100 \mu \mathrm{m}$. 1. Haplophragmoides multicamerus Krasheninnikov, Section 103-641A-2X, CC. 2. Haplophragmoides multicamerus Krasheninnikov, Section 103-641A-1X, CC. 3. Haplophragmoides sp. cf. decussatus Krasheninnikov, Section 103$641 \mathrm{~A}-4 \mathrm{X}, \mathrm{CC} . \quad$ 4-6. Haplophragmoides perexplicatus Krasheninnikov, Sample 603B-30-5, 90-94 cm. 7. Haplophragmoides fraudulentus Krasheninnikov, Section 103-641A-4X, CC. 8. Haplophragmoides fraudulentus Krasheninnikov, Sample 103-641A-4X-1, 58-61 cm. 


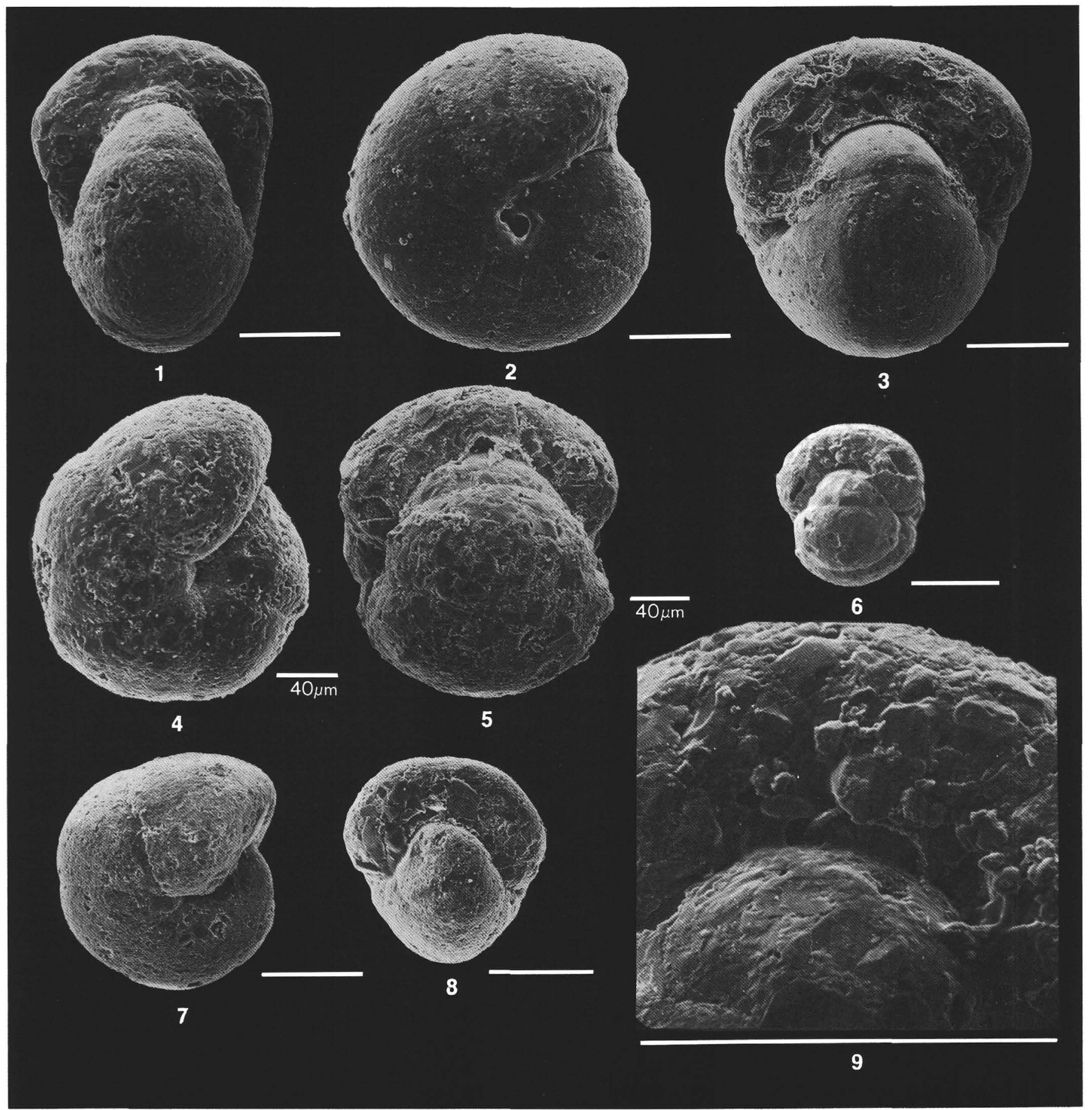

Plate 6. Unless specified, scale bars equal $100 \mu \mathrm{m}$. 1 and 2. Haplophragmoides sp. cf. gr. herbichi Neagu-linki Nauss, Section 103-641A4X, CC. 3. Haplophragmoides bulloides (Beissel), Sample 103-641A-5X-2, 49-53 cm. 4 and 5. Haplophragmoides(?) sp. cf. bulloides (Beissel), Sample 103-641A-6X-7, 26-29 cm. 6. Haplophragmoides(?) sp. cf. bulloides (Beissel), Sample 603B-33-1, 38-42 cm. 7 and 8. Haplophragmoides bulloides (Beissel), Sample 103-641A-5X-2, 49-53 cm. 9. Detail of specimen shown in Figure 6. 


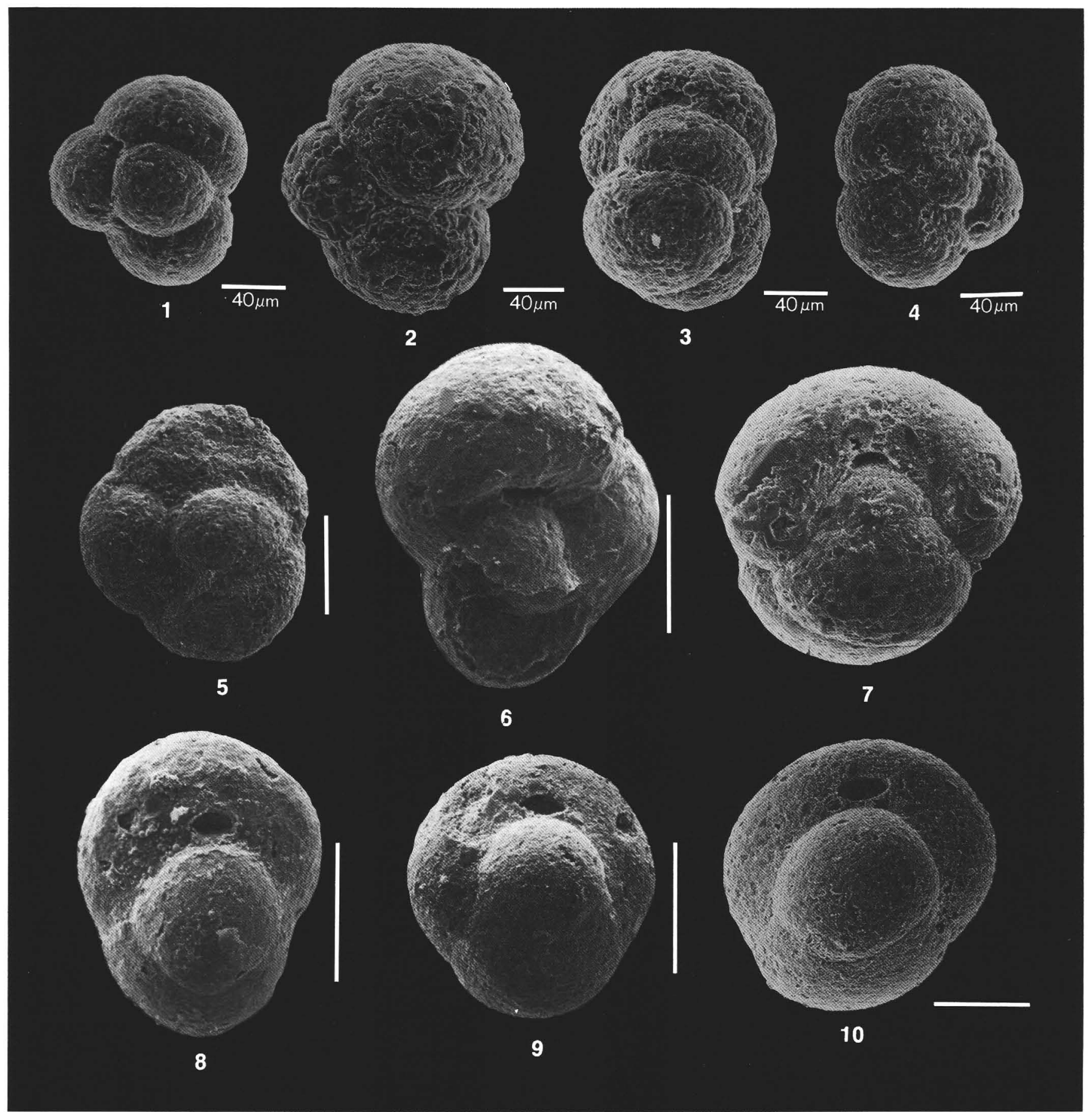

Plate 7. Unless specified, scale bars equal $100 \mu \mathrm{m}$. 1-4. Praecystammina(?) sp. aff. globigerinaeformis Krasheninnikov, Sample 103-641A-6X-6, 33-37 cm. 5. Praecystammina(?) sp. cf. globigerinaeformis Krasheninnikov, Section 103-641A-5X, CC. 6. Praecystammina globigerinaeformis Krasheninnikov, Sample 103-641A-2X-2, 0-3 cm. 7. Haplophragmoides pseudokirki Krasheninnikov, Sample 103-641A-6X-7, 26-29 cm. 8. Labrospira pacifica Krasheninnikov, Section 103-641A-1X, CC. 9. Labrospira inflata Krasheninnikov, Section 103-641A-4X, CC (specimen intermediate to L. pacifica?). 10. Labrospira inflata Krasheninnikov, Sample 103-641A-4X-1, 48-52 cm. 


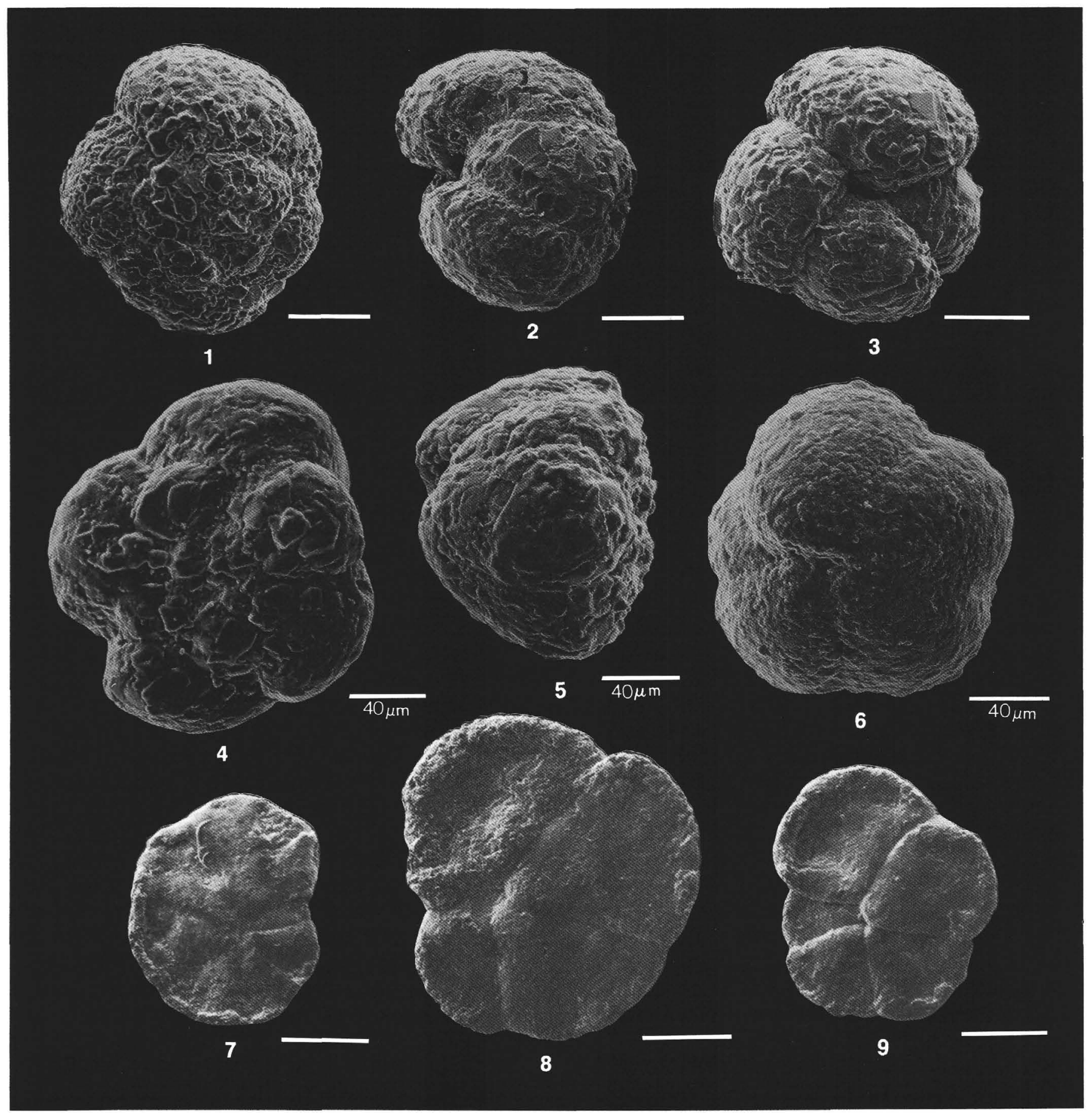

Plate 8. Unless specified, scale bars equal $100 \mu \mathrm{m}$. 1-3. Trochammina altiformis Cushman and Renz, Section 603B-29, CC. 4-6. Trochammina gyroidinaeformis Krasheninnikov, Section 603B-31, CC. 7. Haplophragmoides sp. cf. walteri (Grzybowski), Section 603B-32, CC. 8 and 9. Haplophragmoides sp. cf. concavus (Chapman), Section 603B-32, CC. 


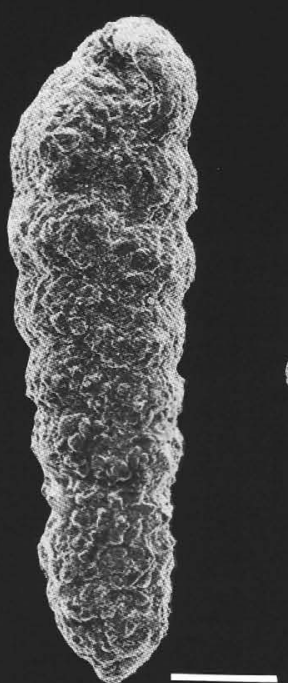

1

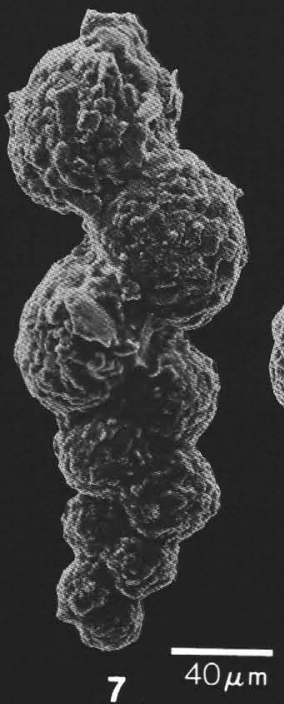

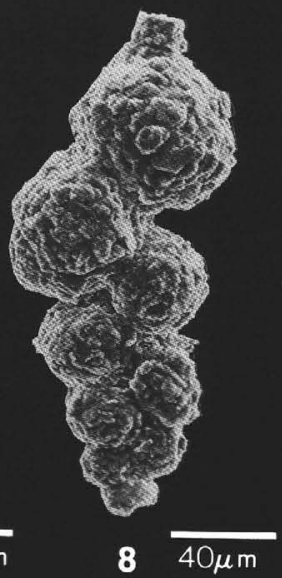

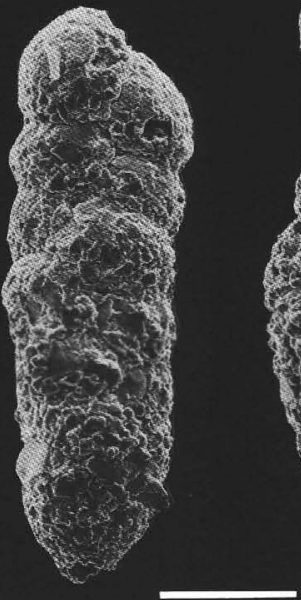

2

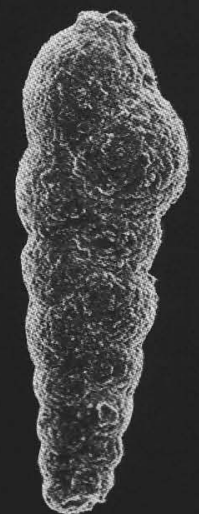

9

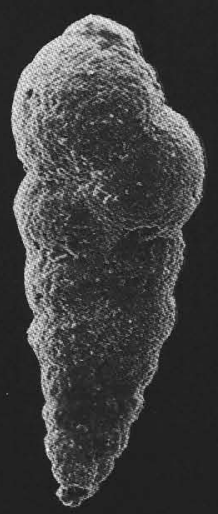

10

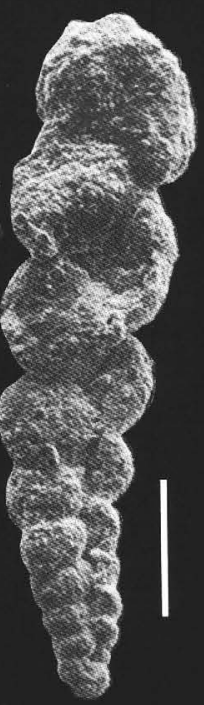

11

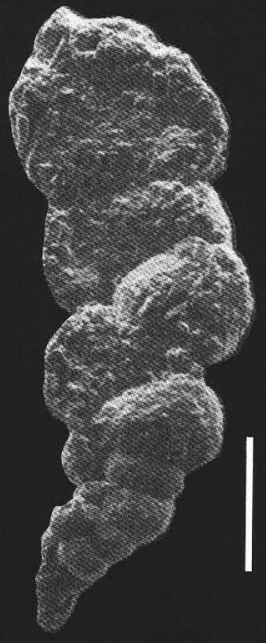

12

Plate 9. Unless specified, scale bars equal $100 \mu \mathrm{m}$. 1. Plectina conversa (Grzybowski), Sample 603B-30-4, 90-94 cm. 2 and 3. Plectina conversa (Grzybowski), Section 603B-31, CC. 4. Plectina sp. aff. lenis (Grzybowski), Section 103-641A-5X, CC. 5. Pseudobolivina sp. 1, Sample 603B-31-4, $54-57 \mathrm{~cm}$. 6. Pseudobolivina sp. 1, Sample 603B-33-1, 90-93 cm. 7 and 8. Pseudobolivina lagenaria Krasheninnikov, Sample 603B-31-4, 54-57 cm. 9 and 10. Pseudobolivina munda Krasheninnikov, Section 603B-30, CC. 11. Pseudobolivina(?) sp. 2, Sample 603B-32-1, 93-95 cm. 12. Pseudobolivina(?) sp. 2, Section 603B-32, CC. 


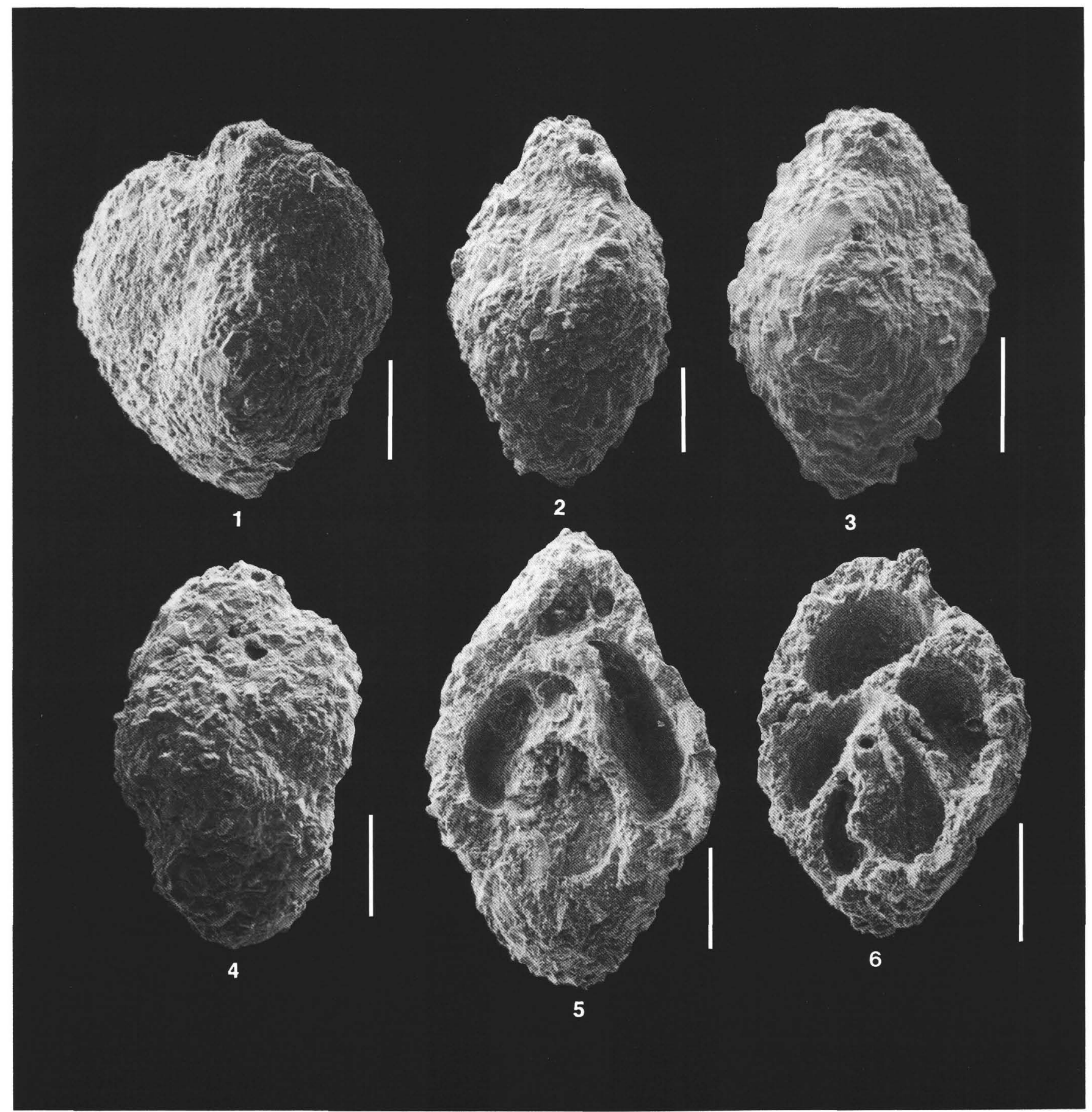

Plate 10. Scale bars equal $100 \mu \mathrm{m}$. 1-6. Uvigerinammina jankoi Majzon: morphologic variability (1-4) and internal organization (5 and 6). 1, 5, and 6. Sample 603B-25-1, 90-94 cm. 2 and 4. Sample 103-641A-5X-1, 5-9 cm. 3. Section 103-641A-4X, CC. 